IZA DP No. 7917

Circumstantial Risk: Impact of Future Tax Evasion and Labor Supply Opportunities on Risk Exposure

Philipp Doerrenberg

Denvil Duncan

Christopher Zeppenfeld

January 2014 


\title{
Circumstantial Risk: Impact of Future Tax Evasion and Labor Supply Opportunities on Risk Exposure
}

\author{
Philipp Doerrenberg \\ Centre for European Economic Research (ZEW), \\ IZA and CGS at University of Cologne \\ Denvil Duncan \\ SPEA, Indiana University \\ and IZA \\ Christopher Zeppenfeld \\ CGS at University of Cologne
}
Discussion Paper No. 7917
January 2014

IZA

P.O. Box 7240

53072 Bonn

Germany

Phone: +49-228-3894-0

Fax: +49-228-3894-180

E-mail: iza@iza.org

Any opinions expressed here are those of the author(s) and not those of IZA. Research published in this series may include views on policy, but the institute itself takes no institutional policy positions. The IZA research network is committed to the IZA Guiding Principles of Research Integrity.

The Institute for the Study of Labor (IZA) in Bonn is a local and virtual international research center and a place of communication between science, politics and business. IZA is an independent nonprofit organization supported by Deutsche Post Foundation. The center is associated with the University of Bonn and offers a stimulating research environment through its international network, workshops and conferences, data service, project support, research visits and doctoral program. IZA engages in (i) original and internationally competitive research in all fields of labor economics, (ii) development of policy concepts, and (iii) dissemination of research results and concepts to the interested public.

IZA Discussion Papers often represent preliminary work and are circulated to encourage discussion. Citation of such a paper should account for its provisional character. A revised version may be available directly from the author. 


\section{ABSTRACT \\ Circumstantial Risk: Impact of Future Tax Evasion and Labor Supply Opportunities on Risk Exposure*}

This paper examines whether risk-taking in a lottery depends on the opportunity to respond to the lottery outcome through additional labor effort and/or tax evasion. Previous empirical attempts to answer this question face identification issues due to self-selection into jobs that facilitate tax evasion and labor effort flexibility. We address these identification issues using a laboratory experiment $(\mathrm{N}=180)$. Subjects have the opportunity to invest earned income in a lottery and, depending on randomly assigned treatment states, have the opportunity to respond to the lottery outcome through evasion and/or extra labor effort. We find strong evidence that ex-post access to labor opportunities reduces ex-ante risk willingness while access to tax evasion has no effect on risk behavior. We discuss possible explanations for this result based on the existing literature.

JEL Classification: $\quad \mathrm{G} 11, \mathrm{H} 21, \mathrm{H} 24, \mathrm{H} 26, \mathrm{~J} 22$

Keywords: $\quad$ tax evasion, labor supply, risk behavior, lab experiment

Corresponding author:

Philipp Doerrenberg

ZEW Mannheim

$\mathrm{L} 7,1$

68161 Mannheim

Germany

E-mail: doerrenberg@zew.de

\footnotetext{
"Financial support from "KölnAlumni - Freunde und Förderer der Universität zu Köln e.V." is gratefully acknowledged. We would like to thank Peter Kuhn, Andreas Peichl, Bettina Rockenbach, Justin Ross, Christian Weyand, and participants at the 2013 Economic Science Association World Conference (Zurich), the 2013 National Tax Association conference and Colby College's department of economics seminar series for helpful comments and suggestions. The usual disclaimer applies.
} 


\section{Introduction}

Although approximately $94 \%$ of households in the United States hold some type of financial asset, there is significant variation in the type and amount of financial assets held (Bricker et al. 2012). For example, 15\% of families hold stocks, 50\% hold retirement accounts, $8.7 \%$ hold pooled investment accounts and $92.5 \%$ hold transaction accounts. ${ }^{1}$ Financial asset holdings also vary greatly across individual and household characteristics. While $24.5 \%$ of households headed by self-employed individuals have stocks in their portfolios, only $13.8 \%$ of households headed by employed individuals do. Additionally, the trends described by Bricker et al. (2012) show evidence of significant variation in risk exposure. For example, the median amount of money invested in bonds by an employed household is approximately eight times as much as that invested in stocks; the comparable ratio for self-employed households is five. There is also evidence of variation in risk exposure across other individual and household characteristics: age, family structure, education level, race and income. An extensive literature in finance and economics has been devoted to explaining these observed variations in risk exposure. Two questions that have received a lot of attention are: how do investors decide how much of their income to invest in risky assets and why do some individuals have greater risk exposure than others (Heaton and Lucas 2000).

The theoretical finance literature has provided many insights into this problem. For example, Heaton and Lucas (2000) argue that if risk decisions are driven by utility maximizing behavior then the drivers of risk exposure can be separated into two broad categories: risk preference and 'circumstances'. It is clearly the case that some individuals are more risk averse than others and that this variation in risk preference affects the amount of risk to which individuals voluntarily expose themselves. 'Circumstances' generally refer to the future opportunities individuals know they will have access to at the time of making risky investment decisions. These circumstances usually have two features - flexibility and background risks - that may have opposing effects on risk exposure. Flexibility acts as a type of insurance against adverse outcomes and is therefore predicted to increase risk exposure (Bodie et al. 1992; Franke et al. 2011). For example, the ability to vary labor hours or take an additional job maybe used as insurance against negative investment outcomes and therefore increase current risk exposure. Future opportunities with uncertain and uninsurable income also represents a type of background risk that

\footnotetext{
${ }^{1}$ These statistics are taken from the Survey of Consumer Finances. Bricker et al. (2012) provides a detail summary of the results including definitions of the various financial assets. Transactions accounts include checking, savings, and money market deposit accounts; money market mutual funds; and call or cash accounts at brokerages. Retirement accounts include personally established individual retirement accounts (IRAs) or job-based 401(k) accounts. Pooled investment funds exclude money market mutual funds and indirectly held mutual funds and include all other types of directly held pooled investment funds, such as traditional open-end and closed-end mutual funds, real estate investment trusts, and hedge funds.
} 
may cause the current risk exposure of individuals to increase, decrease or remain unchanged depending on the form of risk aversion (Gollier and Zeckhauser 2002). As a result, the impact of background risk on current risk exposure remains an empirical question. Furthermore, because future 'circumstances' generally include both flexibility and background risk, which may have opposing effects on risk exposure, the impact of future 'circumstance' on current risk exposure is also an empirical question. Understanding the impact of the interaction of these two characteristics is also important, but difficult to determine in a theoretical framework.

Empirical efforts to identify the impact of circumstances produce inconclusive results. For example, Benitez-Silva (2002) tests the theory in the context of labor supply flexibility and find that individuals who have flexible work hours tend to hold significantly more (risky) stocks. Although this result is consistent with the theoretical work of Bodie et al. (1992), there remains some identification concerns due to self-selection. To the extent that individuals with greater labor supply flexibility also have greater preference for risk exposure, it is not clear that the identified effect is due to labor supply flexibility or risk preferences. ${ }^{2}$ The empirical efforts to identify the impact of background risk is more extensive, but the results are mixed. Although a number of studies find that the presence of background risks reduce risk exposure, the magnitude of the effect varies (Heaton and Lucas 2000). A more recent study by Klos (2004) find that access to a future risky investment has no effect on current risk exposure. This finding not only runs opposite the flexibility argument, the results are also different from the results summarized in Heaton and Lucas (2000). More importantly, the results from the existing literature suggest that the impact of background risk depends on the source of background risk; labor income seems to reduce risk exposure while investment income seems to have little or no effect on risk exposure.

We contribute to this literature by identifying whether access to future labor and tax evasion opportunities affect current risk exposure. In particular, our research question is: Does the opportunity to earn additional labor income and/or evade taxation affect risky asset investment? By studying these two sources of flexibility and background risk in the same setting, we are able to cleanly identify the impact of both circumstances as well as their interaction on risk exposure. We are also able to determine if the effects depend on the type of circumstance. In particular, does the effect of labor income background risk differ from the effect of tax evasion background risk?

As indicated above, answering these questions with observational data leads to identification problems that are very difficult to overcome. Namely, it can be presumed that individuals with a high intrinsic willingness to take risks self-select into occupations

\footnotetext{
${ }^{2}$ To our knowledge, Benitez-Silva (2002) is the only paper to study the link between labor supply flexibility and portfolio choice empirically.
} 
with greater access to tax evasion and additional labor supply opportunities such as selfemployment (Cramer et al. 2002; Hartog et al. 2002). As a result, a positive empirical correlation between self-employment and risk willingness is difficult to interpret in a causal manner, and is instead likely to be confounded by intrinsic, personality-based risk willingness. For clean identification, one would ideally like to randomly assign labor supply and tax evasion opportunities to different workers. Because this is not feasible in the real world, we design a laboratory experiment where each subject participates in a labor task and then makes an investment decision. Subjects are then given an opportunity to respond to the outcome of the lottery before paying taxes. The opportunity to respond to the outcome of the lottery depends on the group to which subjects are randomly assigned: some subjects can evade taxes; some can supply extra labor; some can both evade taxes and supply extra labor; and some can neither evade taxes nor supply extra labor.

Our results show that the opportunity for labor supply and tax evasion have different effects on risk taking and partly cancel each other. The control group, which lacked opportunities for additional labor supply or tax evasion, invested $38 \%$ of their gross income into the risky asset. Access to extra labor opportunities reduces the investment share by approximately eleven percentage points. This represents a thirty percent decrease from the baseline that is statistically different from zero. Evasion opportunity has no effect on the investment share - neither economically nor statistically. When subjects can both supply extra labor and evade taxes, the investment share is 3.5 percentage points lower than in the baseline treatment, but this difference is not statistically different from zero. These results are in line with the theoretical and empirical literature on background risk, which support a negative relationship between uninsurable future risks and current risk exposure(Heaton and Lucas 2000). More importantly, our findings suggest that the effect of background risk depends on the source of background risk. While labor income uncertainty reduces risk exposure as in (Gakidis 1997), the zero tax evasion effect is in line with Klos (2004) who finds that current risk exposure is not affected by the presence of future independent risks.

Our paper contributes to the literature in important ways. This is the first known study we are aware of to examine the effect of tax evasion on current risk exposure. ${ }^{3} \mathrm{Al}-$ though the decision to evade taxes is similar to that of other risky decisions, it may have a different effect due to cognitive and morale biases on the part of the investor. Furthermore, it is widely accepted that access to tax evasion opportunities is heterogeneously distributed across individuals. For example, employees who are subject to third-party re-

\footnotetext{
${ }^{3}$ Wrede (1995) theoretically analyzes the joint problem of risk taking and tax evasion in a static economy. He, however, focuses on the effect of taxation on expected utility and does not explicitly study the dynamic effect of evasion opportunities on initial risk behavior. He concludes that eliminating evasion is likely to discourage risk taking.
} 
porting have less opportunity to evade taxes than their counterparts who are not (Kleven et al. 2011). This difference in access to tax evasion has been shown to have an effect on other economic outcomes that are of interest to policy makers. For example, Doerrenberg and Duncan (2012) find evidence that workers with evasion opportunities have different labor supply elasticities with respect to taxes than workers without access to evasion. There is also evidence that tax evasion has both income distributional implications (Alm and Sennoga 2011) and welfare implications (Chetty 2009; Gorodnichenko et al. 2009). Our study contributes to this growing literature by identifying the impact of tax evasion opportunities on risk exposure, which is it-self an important economic variable for policy makers.

We are also the first to identify the impact of future labor supply opportunities on current risk exposure in a laboratory setting. ${ }^{4}$ Existing studies of both labor flexibility and labor income background risk use observational data, which faces identification issues. Using a laboratory setting allows us to cleanly identify the impact of future labor supply opportunities on current risk exposure. Our results also provide some insights into the possible effect of the current incremental shift toward greater flexibility in the labor market - flexi-week work schedules and work-from-home initiatives - on risk exposure. We find no evidence that the added flexibility will increase risk exposure of affected workers. On the contrary, risk exposure is likely to decrease if the added flexibility is accompanied by greater income uncertainty. Additionally, unlike the existing literature, we explicitly account for any possible interaction effects between labor supply and evasion opportunities in our empirical design. Understanding this interaction effect is especially important given that labor flexibility is often bundled with tax evasion opportunities.

The results are also important and timely given a number of other recent developments. For example, the increased scrutiny of offshore bank accounts imply reduced tax evasion opportunities for many high income individuals. Although this change may to lead to higher tax revenues, we show that it is unlikely to affect risk exposure.

The paper proceeds as follows. Section 2 presents the experimental design. We briefly discuss theoretical considerations in section 3 and present results in section 4 . Our findings are discussed in section 5 and section 6 concludes.

\section{The Laboratory Experiment}

Considering the empirical challenges and the impracticality of the ideal field experiment, we employ a laboratory experiment to study the effect of tax evasion and labor supply opportunities on risky investment behavior. The experimental design used to answer

\footnotetext{
${ }^{4}$ Unlike Klos and Weber (2006) who analyze a portfolio-choice setting with exogenous income that was either certain or risky, we explore a case where labor-income risk is endogenous.
} 
our research question is based on widely-accepted experimental designs in the fields of risk behavior (Gneezy and Potters 1997; Thaler et al. 1997; Klos et al. 2005), tax evasion (Alm 2012) and labor supply (Charness and Kuhn 2011). Although the laboratory environment is artificial, we argue that a clean and clear experiment design, such as ours, allows for causal identification of treatment effects. ${ }^{5}$

\subsection{Experimental Design}

We design a one-shot experiment with between-subject variation to answer our research question. The experiment has three stages. First, subjects complete a real-effort task for which they earn experimental currency units (ECU). Second, subjects decide how much of their labor earnings to invest in a risky lottery. Finally, subjects are given an opportunity to respond to the lottery outcome before paying taxes on their income.

The first two stages are identical for all subjects and we solely vary how subjects can respond to the lottery outcome in the third stage. Depending on which of four treatment groups a subject is assigned to, she either has i) no opportunity to respond, or she has the opportunity to respond through ii) additional labor effort, iii) a tax reporting decision, or iv) both extra labor effort and tax reporting. Hence, we cross two dichotomous factors, "evasion opportunity" and "labor-supply opportunity", in a 2x2 fully-factorial design. The following section describes each of the three experimental stages in greater detail and highlights our identification strategy.

The Labor-Task Stage Every subject first completes a labor task that involves moving a set of sliders across a computer screen (Gill and Prowse 2012). ${ }^{6}$ The sliders are initially positioned at zero and can be repositioned to any integer between 0 and 100, inclusive. Subjects are given two and a half minutes (150 seconds) to align 48 sliders at position 50. Subjects receive instant feedback on the position of the current slider only; this is indicated at the rightmost end of each slider. We disable the arrow keys on the key board to ensure the subjects only use the left mouse key to complete the task; use of the arrow keys makes the task trivial. Additionally "... no two sliders are aligned exactly one under the other" (Gill and Prowse 2012). This design feature prevents subjects from positioning one slider at 50 and then visually matching the other sliders at this position. Subjects are paid an exogenously determined piece rate, which is fixed at 2.5 ECU for

\footnotetext{
${ }^{5}$ We provide a thorough discussion of the external validity of our experimental design and results in section 5.3.

${ }^{6}$ See figure 3 in the appendix for a screenshot of the task. Gill and Prowse (2013a) provide details and show how to implement the slider task. It has been used widely since its introduction: Gill and Prowse (2013b), Riener and Wiederhold (2011), Cettolin and Riedl (2011), Gill and Prowse (2012), and Hammermann et al. (2012). Djawadi and Fahr (2012) also use the slider task in the context of tax compliance, but examine a different research question than we do and employ compliance as the dependent variable.
} 
each correctly-aligned slider. We used an exchange rate of 5 ECU to 1 EUR. Therefore, each subject earned 0.5 EUR for each correctly aligned slider.

The slider task has a number of advantages that are described in Gill and Prowse (2012). It is easy to explain and implement, does not require prior knowledge, does not allow guessing, and most importantly, is identical across treatments and subjects. Although the number of correctly aligned sliders has been used as a measure of labor effort in the labor literature, our primary objective here is to induce a sense of ownership of income and the possibility to consider labor income as a potential background risk. We argue that participants are more likely to make reasonable and "realistic" decisions in a situation with endogenous incomes, relative to a situation with an exogenous endowment. Furthermore, individual variability in outcomes suggests that labor income may be viewed as uncertain. Subjects perform one full round of the slider task as an unincentivized practice round to familiarize themselves with the task.

Investment Stage Subjects are given an opportunity to invest a share of their labor earnings in a lottery after completing the labor task. They are allowed to invest any amount between zero and their total labor earnings in the lottery. The lottery is binary and the amount invested in the lottery is either doubled or halved with equal probability. The actual outcome of the lottery is determined by the throw of a ten sided die. One of the experimenters walks up to each subject's booth after the investment decision is complete and throws a ten sided die. The amount invested in the lottery is doubled if the number on the face of the die is less than or equal to five, and halved if the number on the face of the die is greater than or equal to six. The experimenter enters the number on the face of the die on the computer and the subject verifies that the number is correct before hitting enter. The computer then reports the outcome of the lottery to the subject along with her post-lottery income. ${ }^{7}$

The lottery is designed such that the expected pay-off is greater than the invested amount, i.e., the expected return is positive, which implies that a risk-averse person invests a strictly positive share of his wealth into the lottery. The binary structure and the conditional investment outcomes are easy to grasp and calculate. However, we also provided a computerized calculator at every decision stage.

Response to the Lottery Outcome (Treatment Groups) The next stage of the experiment gives subjects an opportunity to respond to the outcome of the lottery. Recall that our research objective is to determine whether an individual's risk exposure is affected by opportunities to respond to the outcome of risky decisions via tax-evasion and/or labor-supply opportunities. Therefore, we randomly assign subjects to four groups

\footnotetext{
${ }^{7}$ Note that the experimenter could at no point see the amount invested by the subject as the feedback screen was only shown after the experimenter went on and the subject clicked the "next" button.
} 
that are identical in every way except in how they can respond to the outcome of the lottery. Following the $2 \times 2$ crossing, the four cells read as follows: Some subjects have no opportunity to respond, i.e., they can neither supply extra labor nor evade taxes; some subjects can supply extra labor; some subjects can evade taxes; and finally, some can both evade taxes and supply extra labor. In other words, a subject's ability to respond to the outcome of the lottery depends on which of the following groups she is randomly assigned to:

- Baseline: Subjects in the baseline group do not have an opportunity to respond to the outcome of the lottery. After the lottery outcome is realized, their total income is taxed at a proportional rate of 30 percent, and they are simply informed of their final payoff (their net income). The tax rate is fixed exogenously, and is the same for all subjects and all groups. Therefore, subjects in the baseline treatment cannot respond to the lottery. This group serves as the control treatment.

- Labor: After the outcome of the lottery is determined, subjects in the labor treatment play another round (90 seconds) of the real-effort task and thereby earn additional income. After this second round of supplying labor effort, their total income is taxed and subjects are informed of their final payoff (their net income). Therefore, subjects in the labor treatment can respond to the lottery only through a second labor supply choice.

- Evasion: In the evasion treatment, subjects have to make a tax reporting decision. After they learn the outcome of the lottery, participants are asked how much income they wish to report for tax purposes. As is standard in the experimental tax evasion literature, there is an exogenous probability that the tax evasion decision is audited, and a penalty applies in the case of audit and underreporting. After the reporting decision has been made, the audit status is determined and the payoff (net income) is paid accordingly. Therefore, subjects in the evasion treatment can respond to the lottery only through their reporting decision.

- Full: Subjects in the full treatment group have two channels to respond to the lottery outcome. They play another round of the real effort task (90 seconds), as in the labor group, and then make an income reporting decision, as in the evasion group. Their final payoff (net income) is a function of the two rounds of labor supply, the investment decision, the lottery outcome, the reporting decision, and the audit status. Therefore, subjects in this fourth treatment group have access to two channels to respond to the lottery outcome: evasion and labor supply.

Subjects are only informed of the set-up of the experiment in their treatment state, and they receive this information prior to the initial labor supply and investment decisions 
(in the paper based instructions). Therefore, subjects know ex ante whether and how they are able to respond to the lottery outcome, and that they can only respond ex post.

Tax and Audit Mechanism As indicated above, all subjects face an exogenously determined proportional marginal tax rate of 30 percent. $^{8}$ Additionally, subjects in the evasion and full treatments face an exogenous audit probability of 10 percent and a penalty that is equal to twice any evaded taxes due (i.e., a fine rate of 2 ). The audit outcome is determined by the throw of a 10-sided die; subjects are audited if the number one is shown on the face of the die. ${ }^{9}$ Audit leads to the discovery of true income, and subjects who underreport their income pay a penalty equal to twice their evaded taxes (i.e., the underreported amount multiplied by twice the tax rate). All other subjects who either report honestly or underreport but throw a die number between two and ten receive a net income equal to their true gross income less the tax rate multiplied by the reported income. This audit and penalty structure is commonly used in the tax evasion literature (Alm et al. 2009). In order to make the tax reporting decision as realistic as possible, we include an exogenous audit risk and donate all tax revenues and fines to the administrative governing body of the City of Cologne, Germany. ${ }^{10}$

We argue that this is the cleanest experimental design to answer the research question posed above: a one-shot game in a between-subject design that produces 180 independent observations (45 per treatment) on a metric dependent variable. We are therefore guaranteed sufficient statistical power to answer our research question. All participants face the same labor effort, investment decision, and marginal tax rates, and therefore only differ with respect to the channel that is available to respond to the lottery outcome ex post. This allows us to compare the share of income invested in the lottery across the four groups and attribute any differences to the difference in response opportunities. Additionally, since subjects know ex ante whether and how they are able to respond to the lottery outcome, and that they can only respond ex post, any treatment effect we identify must be driven purely by anticipation of the response opportunity. Methodologically, this is achieved by changing only that part of the instructions governing second-period

\footnotetext{
${ }^{8}$ Because subjects in the baseline and the labor treatment do not make an income reporting decision, they pay 30 percent on their total income in taxes. On the other hand, subjects in the evasion and full treatment groups pay a tax rate of 30 percent on their reported income because they are able to respond to the lottery outcome by underreporting income.

${ }^{9}$ The procedure was as follows: After the reporting decision was complete for the evasion and full treatment groups, one of the experimenters walked up to each computer booth and threw a 10-sided die; the experimenter entered the number on the face of the die on the computer; the subject confirmed this number, which results in a screen with one of the following sentences: You have been audited or You have not been audited. The subject had to press "ENTER" again to see the screen summarizing the round's payment. By this time the experimenter had already moved on to the next subject. Hence, the experimenter could at no point see subjects' reported share.

${ }^{10}$ Subjects received a copy of the donation receipt (stating the total amount donated) via e-mail after the experiment has been conducted. This procedure was also explicitly stated in the instructions.
} 
opportunities; the first period is identical across instructions.

\subsection{Organization}

The experiment was conducted in the Cologne Laboratory for Economic Research (CLER), University of Cologne, Germany. A random sample of the laboratory's subject pool of approximately 4000 persons was invited via email - using the recruitment software ORSEE (Greiner 2004) - to participate in the experiment. Potential participants signed up on a first-come-first-serve basis. A total of 180 subjects, mostly undergraduate students from the University of Cologne, participated in the experiment (see section 4.1 for summary statistics). Neither the content of the experiment nor the expected payoff were stated in the invitation email. The computerized experiment was programmed utilizing $z$-tree software (Fischbacher 2007).

We conducted twelve sessions over three regular school days in May and June $2013 .{ }^{11}$ Each session included one practice round, one paying round, 15 subjects, and lasted approximately 40 minutes on average (including review of instructions and payment of participants). The exchange rate between Experimental Currency Units (ECU) and Euro was such that five ECU corresponded to one Euro. Random assignment to computer booths was implemented by asking each subject to draw an ID number out of a box upon entering the lab. The decisions and payments of the subjects were linked to their ID and the experimenter had no way of matching this information to their names. Subjects also received a hard copy of the instructions when they entered the lab (See appendix D) and were allowed as much time as they needed to familiarize themselves with the procedure of the experiment. They were then given the opportunity to ask any clarifying questions in private.

\section{Theoretical Background}

In this section, we discuss the conditions under which the opportunity to react to the investment outcome in the future affects the current exposure to investment risks. Agents maximize the expected utility of terminal wealth given disutility of effort, i.e., working. Agents have direct utility function $u$ which is strictly increasing and strictly concave in wealth $z$. Effort causes increasing and convex $\operatorname{costs} c$. We consider a two-period economy.

In the first period, the agent is endowed with an initial endowment $w_{0}$ and can work to gain additional income. Subsequently, he decides how much of his total period-one wealth to invest in a risk-free storage and how much to invests in a risky asset. The

\footnotetext{
${ }^{11}$ There are two regular semesters at the tertiary level in Germany; winter semester lasting from October to March and Summer Semester between April and July. Therefore, the experiment was implemented during the regular lecture season.
} 
risk-free rate is zero. The risky asset has a random return $\tilde{r}$ distributed according to the cumulative distribution function $F(r)$ with $E_{F} \tilde{r}>0$.

In the second period, the agent learns the realization of $\tilde{r}$. Depending on the treatment, he either has different opportunities to further increase his wealth or not. Final gross wealth is subject to taxation at rate $0<t<1$. To increase his wealth, the agent can either work again for additional income, or he can evade taxes by underreporting his true final wealth, or both.

\subsection{The Baseline Problem without Adjustment Opportunities}

We begin by characterizing the agent's optimal action when he has no adjustment opportunities in period two. The agent faces the following static objective:

$$
\max _{l_{1}, a} E_{F} u\left(\left(w_{0}+w l_{1}-a\right) \tau+a(1+\tilde{r}) \tau\right)-c\left(l_{1}\right)=\max _{l_{1}, a} E_{F} u\left(w_{0} \tau+w \tau l_{1}+a \tau \tilde{r}\right)-c\left(l_{1}\right),
$$

where $w>0$ is the wage rate per unit of work, $l_{t}$ is the units worked in period $t=1,2$, and $a \geq 0$ is the absolute amount invested in the risky asset. For brevity, we write $\tau=1-t>0$.

It is well-known that an agent invests a positive fraction of his wealth in the risky asset due the positive expectation of excess returns (e.g., Gollier 2001). Call the solution to the static problem without adjustment opportunities $a_{\text {NoAdjust }}$.

We now turn to the conditions under which adjustment opportunities in the second period leads to increased or decreased risk taking in the first period. That is, the conditions under which adjustment opportunities increase or decrease $a$. For this, it is sufficient to show that these opportunities reduce (increase) the agent's risk aversion, or increase (reduce) his risk tolerance, respectively, in the first-period problem. More specifically, the agent's value function $v$ in the dynamic problem has to be less (more) concave than the direct utility function $u$ in the sense of Arrow (1965) and Pratt (1964).

\subsection{The Dynamic Problem with Adjustment Opportunities}

Consider an agent who faces the same first-period portfolio choice as in the baseline problem but knows that he will have an adjustment opportunity in the subsequent period. The discussion of his optimal investment results from backward induction.

In the second period, the investment return realizes and the agent observes the resulting wealth $z \equiv z\left(l_{1}, a ; r\right)$. Hence, the set of outcomes from first-period decisions is entirely captured by the resulting wealth $z$ which is the state variable in the dynamic problem. In period two, the agent may now respond to the realization of $z$. Consequently, the agent decides on units of work, $l_{2}$, or the amount of wealth evaded, $e$, i.e., the amount 
of non-reported income, or both.

Future income with positive variance may serve as an insurance against adverse current investment outcomes but can also be seen as a background risk relative to the current period-one risk. Hence, it depends on the shape of risk aversion and risk tolerance, respectively, whether first-period risk taking is actually increased in the presence of adjustment opportunities or whether the agent chooses to be less exposed to current investment risk.

\subsubsection{Labor Supply Opportunity}

We first examine how the opportunity to adjust labor supply in the second period affects risk taking in the first period. The opportunity to supply additional labor represents the ability to respond to the risky investment outcome by additional effort. For each unit of work, $l_{2}$, the agent receives wage $w$ but also suffers costs $c\left(l_{2}\right)$.

Bodie et al. (1992) and Franke et al. (2011) show that under non-stochastic income, agents increase their risky investment. Intuitively, a certain way to increase income expost serves as a kind of insurance towards adverse investment outcomes. The agent knows that he will be able to offset potential losses. Non-stochastic income substitutes the risk-free storage and the agent invests a larger fraction of his wealth in the risky asset.

Note, however, that income in our experiment is not unambiguously predictable. Given the real-effort task utilized in the experiment, it is hard for the subjects to anticipate their productivity in the second period. As we will show later, subjects exhibit a large variability in their performance. This limits their ability to forecast to what extent they will be able to offset potential losses. We capture this uncertainty by allowing the agent to tremble, i.e., we add some noise, $\tilde{\eta} \sim G(\eta)$, to his effort choice.

Hence, in period 2, the investor has the following value function

$$
v^{l_{2}}=\max _{l_{2}} E_{G} u\left(z \tau+w \tau\left(l_{2}+\tilde{\eta}\right)\right)-c\left(l_{2}\right)
$$

The first-period problem is hence given by

$$
\max _{l_{1}, a} E_{F} v^{l_{2}}\left(w_{1}+a \tilde{r}\right)-c\left(l_{1}\right)
$$

Call the solution to the dynamic problem with labor-supply opportunity $a_{\text {Labor }}$. The difference between the first-period problem without adjustment opportunities (1) and (3) is that the agent now maximizes a different objective function. He will invest more in the risky asset, i.e., $a_{\text {Labor }}>a_{\text {NoAdjust }}$, if his value function is less concave than his direct utility function. On the other hand, if his value function is more concave, he will reduce his risk exposure in period one, i.e., $a_{\text {Labor }}>a_{\text {NoAdjust }}$. 
Note that making the agent tremble is equivalent to adding an uncertain non-market component to the overall income. ${ }^{12}$ Uncertain non-market wealth has two effects. First, if the minimum income is bounded away from zero and the variance of this income is sufficiently small, agents should again invest more in the risky asset in the first period (Franke et al. 2011), i.e., $a_{\text {Labor }}>a_{\text {NoAdjust }}$. This is one likely scenario for the performance in the real-effort task. The amount of labor income available from second-round performance varies but can be considered non-negative. However, Franke et al. 2011 also note that this result may not hold if the variance of income is sufficiently large.

Second, consider an agent having problems generating income in the labor task. He will not only generate very low income but he will also have highly convex costs in doing so. Combined, this may yield negative overall utility as marginal costs exceed marginal earnings. Hence, it is possible that for some agents the labor task may actually bear the risk of achieving negative utility though it has a positive expectation in general. Franke et al. 2011 show that in this case risk aversion is range dependent. The more likely a bad performance is, the more risk averse the agent becomes as he tries to avoid negative utility.

\subsubsection{Evasion Opportunity}

We now examine how the opportunity to evade taxes in the second period affects the agent's first-period exposure to investment risks. The opportunity to evade taxes represents the ability to respond to the risky investment outcome by taking an additional risk. We write the tax evasion decision as a second-period portfolio choice in the spirit of Allingham and Sandmo (1972). This allows us to apply the results of Gollier (2001) and Gollier and Zeckhauser (2002) to characterize the conditions under which an additional risk induces more or less risk taking.

One unit of evaded taxes yields a random return $\tilde{\epsilon}$ distributed according to $(p,-\zeta ; 1-$ $p, 0)$, i.e., the tax reporting decision is audited with probability $p>0$ and the fine rate is $\zeta>0$. Starting in the second period, the agent has the following value function

$$
v^{e}(z)=\max E_{P} u(z \tau+e \tilde{\xi})
$$

where $\tilde{\xi} \sim P(\xi)=(p, t-\zeta ; 1-p, t)$ is the excess return per unit of evaded taxes. We model the parameters such that $E_{P} \tilde{\xi}>0$.

By backward induction, in period one, the agent now chooses the amount invested

\footnotetext{
${ }^{12}$ To see this write $z \tau+w \tau\left(l_{2}+\tilde{\eta}\right)=z \tau+w \tau l_{2}+w \tau \tilde{\eta}$. The last term is a random component of wealth that does neither depend on the agent's choices nor on the investment return realization.
} 
in the risky asset that solves the following objective

$$
\max _{a} E_{F} v^{e}\left(w_{0}+a \tilde{r}\right)-c\left(l_{1}\right)
$$

Call the solution to the dynamic problem with tax-evasion opportunity $a_{\text {Evasion }}$. Again, the agent will invest more in the risky asset,i.e., $a_{\text {Evasion }}>a_{\text {NoAdjust }}$ if his value function is less concave than his direct utility function and vice versa.

Gollier and Zeckhauser (2002) show that the opportunity to take an additional risk ex-post leads to more risk taking ex-ante if and only if absolute risk tolerance is convex. Their proposition applies if the second risk has a binary support which holds for our assumption on the auditing mechanism. Note that it is sufficient to assume that risk aversion is concave for a tax-evasion opportunity to induce more risk taking. ${ }^{13}$

Whether risk tolerance is actually convex or concave is an empirical question. Gollier and Zeckhauser (2002) list several empirical observations leading to arguments for either form. Hence, it remains an empirical question whether a subsequent risky decision leads to more risk taking initially. Note that the standard assumption in macroeconomics and finance postulates a linear risk tolerance. Given linearity, a second-period risk does not affect the optimal exposure to first-period risks. Hence, myopic investment decisions are optimal (Mossin 1968).

The theoretical results discussed above suggest that the effect of 'circumstances' on risk exposure is ambiguous. This ambiguity extends to the case with both evasion and labor supply opportunities. Therefore, we rely on an empirical analysis to identify the effects of ex-post opportunities on risk exposure. The results from this analysis are reported in the next section.

\section{Results}

In this section, we first present summary statistics (section 4.1) and simple non-parametric comparisons of the four treatment groups (4.2), before we proceed to regression results in section 4.3 .

\subsection{Summary Statistics}

Summary statistics for demographic and attitudinal variables which were surveyed through a questionnaire at the end of the experiment are presented in Table 1. The demographic

\footnotetext{
${ }^{13}$ Concave risk aversion implies convex risk tolerance and therewith increased risk taking. However, Gollier and Zeckhauser (2002) state the proposition in terms of risk tolerance as this is more useful because they note that risk aversion cannot be decreasing, concave and positive everywhere. As Gollier (2001) notes, the convexity of risk tolerance is rather a restriction on risk aversion not to be too concave.
} 
variables include age, gender and native language. Because our experiment involves making investment and evasion decisions, we ask one question on risk aversion ${ }^{14}$ and one on tax morale. ${ }^{15}$

The summary statistics reported in Table 1 shows that males and native German speakers make up $42 \%$ and $79 \%$ of the sample, respectively, and that the average age is 24.4 years. Randomization into treatment groups worked mostly well as the variables are fairly balanced across treatment groups. Since the share of males is about 9 percentage points lower in the baseline treatment relative to the average share, we provide regression results that control for demographic variables to ensure that our results are not driven by differences in gender or other individual characteristics.

Table 1: Summary Statistics by Treatment Status: Demographic and Attitudinal Variables

\begin{tabular}{lccccc}
\hline & Control & \multicolumn{4}{c}{ Treatments } \\
& Group & Labor & Evasion & Full & Total \\
\hline Age & 25.22 & 23.22 & 24.47 & 24.64 & 24.39 \\
& $(6.842)$ & $(2.779)$ & $(3.546)$ & $(7.371)$ & $(5.512)$ \\
Male & 0.333 & 0.422 & 0.467 & 0.489 & 0.428 \\
& $(0.477)$ & $(0.499)$ & $(0.505)$ & $(0.506)$ & $(0.496)$ \\
German & 0.711 & 0.756 & 0.889 & 0.800 & 0.789 \\
& $(0.458)$ & $(0.435)$ & $(0.318)$ & $(0.405)$ & $(0.409)$ \\
Tax Morale & 7.711 & 7.289 & 6.689 & 6.800 & 7.122 \\
& $(2.427)$ & $(2.873)$ & $(2.670)$ & $(3.005)$ & $(2.760)$ \\
Risk & 1.200 & 1.244 & 1.311 & 1.222 & 1.244 \\
& $(0.505)$ & $(0.609)$ & $(0.668)$ & $(0.599)$ & $(0.594)$ \\
\hline
\end{tabular}

Notes: Reported is the mean of demographic and attitudinal variables by treatment status. Standard deviations in parentheses. $N=180$. Subjects in the Labor and Evasion treatments had the opportunity to supply extra effort and evade taxes, respectively. Full treatment indicates that both labor and evasion adjustments were available. Subjects in the control group had no adjustment opportunities. All information were surveyed through a questionnaire at the end of the experiment.

\subsection{Non-parametric Comparisons of Treatment Groups}

Table 2 presents summary statistics for the choice variables: Labor effort, investment decision and compliance behavior. In the following, we compare the treatment groups

\footnotetext{
${ }^{14}$ The measure of risk aversion is obtained by asking subjects to choose between a certain pay-off of $\$ 50$ and a gamble that pays $\$ 100$ with probability of 0.5 and $\$ 0$ with probability of 0.5 .

${ }^{15}$ The tax morale question is adopted from World Values Survey (Inglehart nd). "Please tell me for the following statement whether you think it can always be justified, never be justified, or something in between: 'Cheating on taxes if you have the chance'." This is the most frequently used question to measure tax morale in observational studies (e.g., Slemrod 2003, Alm and Torgler 2006, and Halla 2012).
} 
with respect to these variables.

Table 2: Summary Statistics by Treatment Status: Choice Variables

\begin{tabular}{lccccc}
\hline & Control & \multicolumn{4}{c}{ Treatments } \\
& Group & Labor & Evasion & Full & Total \\
\hline Effort Practice & 13.31 & 13.51 & 12.69 & 13.47 & 13.24 \\
& $(4.547)$ & $(5.968)$ & $(4.828)$ & $(4.998)$ & $(5.081)$ \\
Effort Round 1 & 17.78 & 18.44 & 17.51 & 17.96 & 17.92 \\
& $(4.680)$ & $(4.429)$ & $(4.841)$ & $(4.472)$ & $(4.583)$ \\
Effort Round 2 &. & 12.20 &. & 11.47 & 11.83 \\
& & $(3.259)$ & & $(2.951)$ & $(3.113)$ \\
Investment share & 0.381 & 0.271 & 0.375 & 0.346 & 0.343 \\
& $(0.297)$ & $(0.206)$ & $(0.267)$ & $(0.279)$ & $(0.266)$ \\
Share Reported &. &. & 0.141 & 0.309 & 0.225 \\
& & & $(0.248)$ & $(0.401)$ & $(0.342)$ \\
\hline
\end{tabular}

Notes: Reported is the mean of choice variables by treatment status. Standard deviations in parentheses. $N=180$. Subjects in the Labor and Evasion treatments had the opportunity to supply extra effort and evade taxes, respectively. Full treatment indicates that both labor and evasion adjustments were available. Subjects in the control group had no adjustment opportunities.

Effort decisions On average, over all treatment groups, roughly 18 sliders were correctly positioned in the first payoff relevant round. Table 2 shows that, labor effort is fairly balanced across the four treatment groups. Though slightly higher in the labor treatment relative to the other groups, this difference in correctly positioned sliders in the first round is not statistically significant (Mann-Whitney test relative to control group: $p=0.4914)$. The slight difference in round 2 effort between the two groups that have the opportunity to respond to the lottery outcome by working is not significant either. ${ }^{16}$

Investment decisions Our main variable of interest is the share of round-one income invested in the lottery, which we simply refer to as investment share. This variable is presented in the fourth row of Table 2 as well as in Figure 1. We observe that the share of round-one income that is invested in the lottery is $38.1 \%$ in the baseline, $27.1 \%$ in the labor treatment, $37.5 \%$ in the evasion treatment, and $34.6 \%$ in the full treatment. There is no statistically significant difference in the investment share between the baseline and evasion treatment (Mann-Whitney test: $p<0.88$ ). Though the investment share in the full treatment is approximately four percentage points lower than the baseline, this difference is not statistically different from zero either (Mann-Whitney test: $p<0.66$ ).

\footnotetext{
${ }^{16}$ Tables 6 and 7 in the Appendix show the distribution of correctly positioned sliders in each treatment group.
} 
On the other hand, we observe a large treatment effect in the labor treatment; the investment share is eleven percentage points lower relative to the baseline. This treatment effect is both economically large and statistical different from zero (Mann-Whitney test: $p<0.066)$.

Our results therefore suggest that the opportunity to provide extra labor effort after learning the outcome of the lottery (ex-post) reduces subjects' willingness to take on investment risk (ex-ante). This effect is almost fully countered if these subjects also have an opportunity to evade taxes. Curiously, subjects whose only response to the investment outcome is to evade taxes are no more or less risky than subjects without response opportunities. The fact that the investment decisions of subjects in the control and evasion groups are close to each other (given that the choice variable is metric between 0 and 1) shows that the significant difference between the labor and control group is very high and reflects a causal treatment effect.

Figure 1: Investment Share by Treatment Group

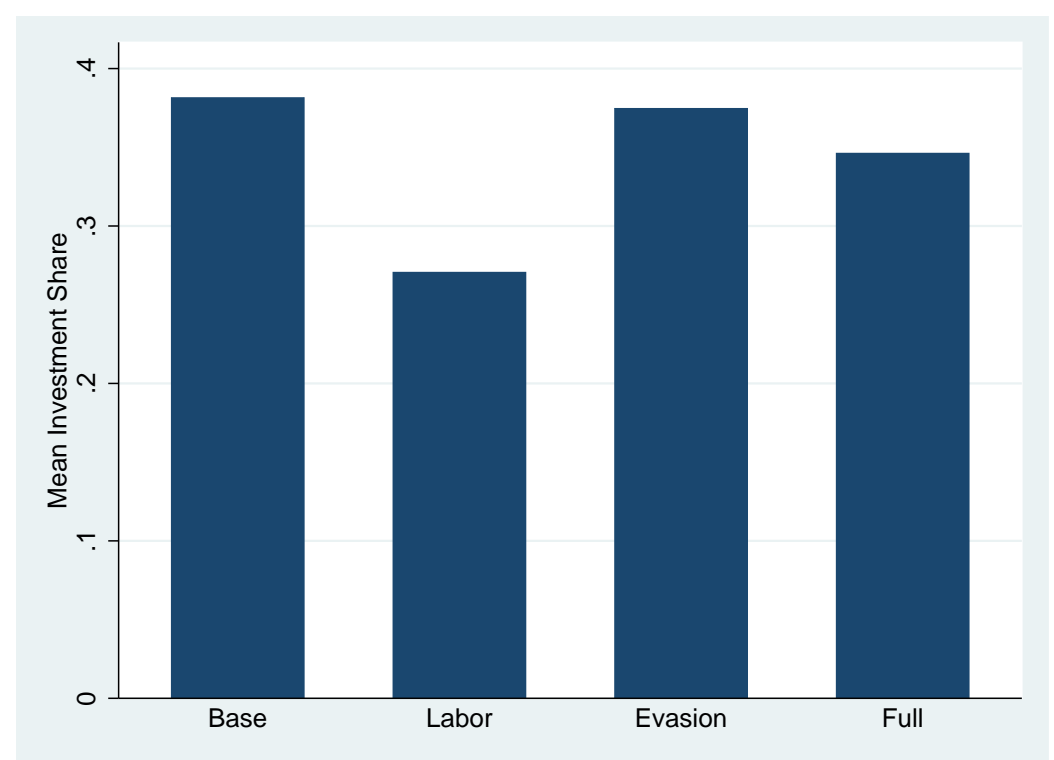

Notes: Reported is the share of round 1 labor income that is invested in the lottery by treatment status. $N=180$. Subjects in Labor and Evasion treatments had the opportunity to supply extra effort and evade taxes, respectively. Full treatment indicates that both labor and evasion adjustments were available. Subjects in the control group had no adjustment opportunities.

Compliance behavior Additional insights come from examining the compliance behavior in the two groups with the opportunity to underreport. On average, subjects in these two groups reported $22.5 \%$ of their income for tax purposes. However, there are large differences between the two groups as can be seen in Figure 2; while subjects in the evasion treatment reported, on average, $14 \%$ of their income, subjects in the full treatment group were more honest and reported almost $31 \%$ of their income. This 17 percentage points difference is statistically different from zero (Mann-Whitney test: 
$p<0.0871)$.

Figure 2: Reporting Behavior by Treatment Group

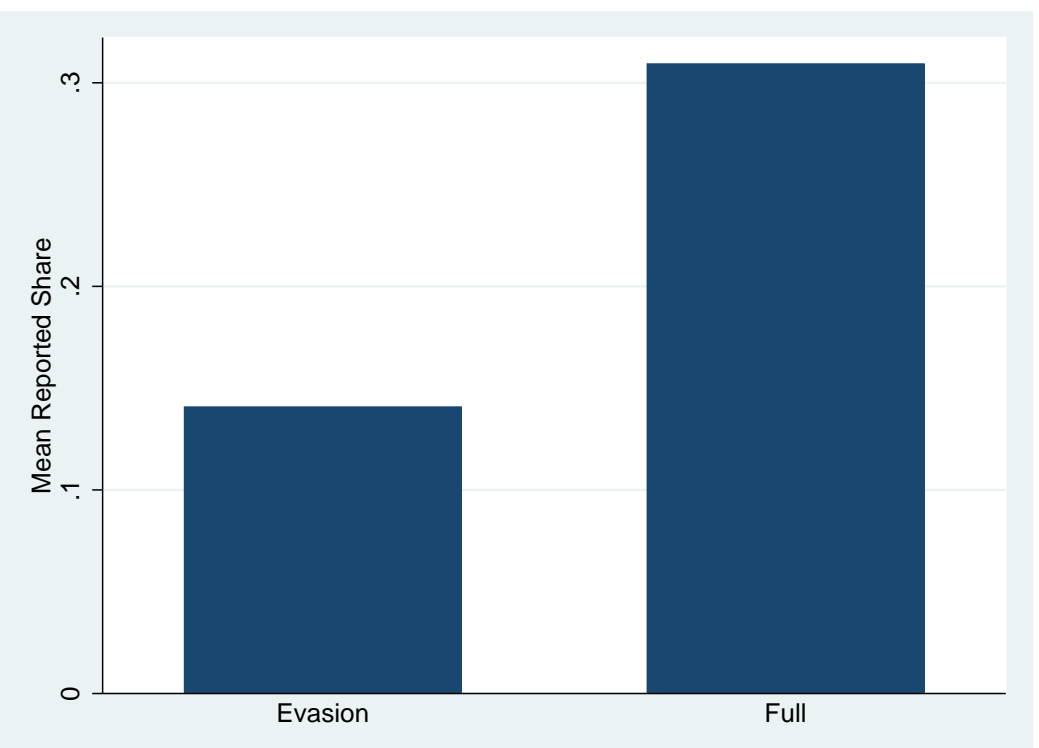

Notes: Reported is the share of income that is reported for tax purposes by treatment group. $N=90$. Subjects in Evasion treatment had evasion adjustment opportunities. Full treatment indicates that both labor and evasion adjustments were available.

\subsection{Regression Results}

This section describes parametric results based on the following regression model:

$$
\psi_{i g}=\alpha+\beta \cdot \text { Treat }_{g}+\phi \cdot \mathbf{X}_{i g}+\epsilon_{i g},
$$

where subscripts indicate a subject $i$ who is in treatment group $g=0,1,2,3$ (with $g=0$ : control, $g=1$ : labor treatment, $g=2$ : evasion treatment, $g=3$ : full treatment). The dependent variable $\psi_{i g}$ is the share of round 1 labor income that is invested in the lottery. Treat $_{g}$ is a categorical indicator variable for a subject's treatment group ${ }^{17}$ and $\beta$ is the coefficient of interest. The coefficients for each treatment group will be relative to the omitted control group with $g=0$. Some specifications also control for demographic and attitudinal variables that are captured in $\mathbf{X}_{i g} . \epsilon_{i}$ is an error term; we use heteroscedasticity-robust standard errors.

Specification (I) of Table 3 shows OLS estimates of the effect of treatment status on the share of invested income. The estimated treatment effects confirm our non-parametric analysis. The investment share of subjects who have the opportunity to provide additional labor effort is 10 to 11 percentage points lower than the control group. This effect is

\footnotetext{
${ }^{17}$ Recall that we employ a between-subjects design where each subject is exclusively in one of the four treatment groups.
} 
large and statistically significant at the $5 \%$ level. On the other hand, the investment share of subjects in the evasion and full treatment groups is not statistically different from that of the control group. These results are robust to the inclusion of demographic and attitudinal variables in specification (II); age, gender, a dummy indicating German as the native language, and the questionnaire answers to the risk and morality questions. The results are also robust to estimating two-censored Tobit regressions (specifications (III) and (IV) ) which account for the fact that subjects were restricted by borrowing constraints, i.e., they could only invest their total income but not more, and they could not short the lottery.

As expected, males and subjects who are characterized as risk seeking invest a larger share of income in the lottery. These estimates are in line with the risk literature and therefore support our claim that the lottery in the experiment captures risk behavior well. For example, Charness and Gneezy (2012) find that males are more risk seeking than women in laboratory experiments. We also find that older subjects invest a larger share of income in the lottery. Although this estimate is statistically different from zero, it is economically small. ${ }^{18}$

Table 3: Treatment Effects on Investment Behavior: OLS and Tobit Regressions

\begin{tabular}{lcccc}
\hline Model & $(\mathrm{I})$ & $(\mathrm{II})$ & $(\mathrm{III})$ & $(\mathrm{IV})$ \\
Estimation & OLS & OLS & Tobit & Tobit \\
\hline Labor & $-0.111^{* *}$ & $-0.102^{* *}$ & $-0.128^{* *}$ & $-0.114^{* *}$ \\
& $(0.054)$ & $(0.051)$ & $(0.063)$ & $(0.057)$ \\
Evasion & -0.007 & -0.018 & -0.016 & -0.027 \\
& $(0.060)$ & $(0.061)$ & $(0.071)$ & $(0.070)$ \\
Full & -0.035 & -0.041 & -0.058 & -0.062 \\
& $(0.061)$ & $(0.058)$ & $(0.073)$ & $(0.069)$ \\
Constant & $0.381^{* * *}$ & $0.261^{* *}$ & $0.387^{* * *}$ & 0.213 \\
& $(0.044)$ & $(0.118)$ & $(0.053)$ & $(0.144)$ \\
\hline Controls & No & Yes & No & Yes \\
N & 180 & 180 & 180 & 180 \\
R2 & 0.028 & 0.176 & 0.030 & 0.219 \\
\hline
\end{tabular}

Notes: OLS and two-censored (at 0 and 1) Tobit regressions based on equation 6. Dependent variable is the share of first period labor income invested in the lottery. Treatment effects are relative to the omitted control group without adjustment opportunities. Subjects in the Labor and Evasion treatments had the opportunity to supply extra effort and evade taxes, respectively. Full treatment indicates that both labor and evasion adjustments were available. Robust standard errors in parentheses. Estimations (II) and (IV) include a full set of control variables (see Table 4 for detailed results). ${ }^{*}<0.10,{ }^{* *}<0.05,{ }^{* * *}<0.01$

\footnotetext{
${ }^{18}$ For details on the measurement of risk and morale see footnotes 14 and 15 . The coefficients for all demographic and attitudinal variables are reported in Table 4 in the Appendix.
} 


\section{Discussion}

Our empirical analysis highlights three important findings: future labor supply opportunity reduces risk exposure, access to evasion has no effect on exposure and, combined, tax evasion nearly fully cancels the labor effect. This section of the paper discusses these findings in the context of the existing theoretical and empirical literature. We also discuss issues of internal and external validity of the experimental design.

\subsection{Discussion of the Results}

The existing theoretical literature suggests that proving individuals with a future income source induces flexibility and background risk effects. While flexibility induces greater risk exposure, background risks may cause current risk exposure to increase, decrease or remain unchanged if individuals are risk seeking, risk averse or risk neutral, respectively. Our findings are consistent with the theoretical results of background risk.

Consider the labor treatment effect. We argue that the future labor effort offered both a means of flexibly responding to the outcome of the lottery and a source of background risk. Flexibility stems from the ability to offset potential adverse return realizations with additional income. Background risk stems from the low predictability of performance in the labor task combined with the disutility of earning income. Although subjects in the labor treatment knew ex-ante that they had an opportunity to supply labor after learning the outcome of the lottery, the income associated with this labor task was unclear for two reasons. First, the difficulty of the slider task implies that subjects could only predict their labor income with large errors. This is confirmed by the large standard deviations on labor effort reported in Table 2. Second, subjects had 150 seconds to complete the first labor task and 90 seconds to complete the second labor task. We argue that this one minute difference in labor time, made it even more difficult for subjects to accurately predict their future labor income based on the income earned in the first labor task. The inability to accurately predict future labor income along with the disutility of completing the labor task suggest that the future labor opportunity acted as both a source of flexibility and labor income background risk. Because we find that subjects in the labor treatment invested a lower share of income in the lottery, our findings suggest that the background risk effect dominated the flexibility effect. ${ }^{19}$

\footnotetext{
${ }^{19} \mathrm{We}$ are not the first to study the effect of flexibility on risk exposure in a laboratory setting. For example, Gneezy and Potters (1997) find that flexibility does not increase risk exposure even though they model flexibility differently than we do. In particular, they conduct a laboratory experiment where subjects make a series of investment decisions. Subjects in one group make their investment decisions for each period separately and receive feedback after each investment. Subjects in the other group make investment decisions for multiple periods simultaneously, and they only receive feedback for each block of investment instead of period by period evaluations. The results from their study show that the first group, which has greater flexibility, exposed their endowment to lower risk. Gneezy et al. (2003) find
} 
Similarly, the opportunity to evade taxes also act as a source of flexibility and background risk. In other words, individuals in the evasion treatment who lose the lottery have the opportunity to underreport income for tax purposes. This lowers their tax payment, increase their net income and thus allows them to recoup some of the income lost in the lottery. At the same time, the probability of being caught and the fine associated with evasion implies a source of background risk as well. Our results show that flexibility and background risk seem to exactly offset each other; evasion opportunity has no effect on risk exposure.

Finally, we find no evidence that having both evasion and labor supply opportunities affect risk exposure. The treatment effect of $3.5 \%$ is not statistically different from zero. This finding suggests that the effect of labor effort on risk exposure is conditional on the presence of evasion. In other words, individuals with labor income background risk will expose themselves to greater risk if they have the opportunity to evade taxes.

This result, along with the contrasting background risk effects in the labor and evasion treatments further imply that the source of background risk matters. This conclusion is supported by existing empirical evidence. For example, our evasion result is similar to that of Klos (2004) who finds that a having a future investment opportunity has no effect on current risk exposure. Our labor supply result is consistent with Gakidis (1997) who finds that individuals with uncertain future labor income have lower risk exposure. ${ }^{20}$ This raises an additional question; why does the source of background risk matter? The existing theoretical literature seems to be mute on this question. ${ }^{21}$

A possible alternative explanation for our results in the labor treatment is income targeting. If subjects begin the experiment with a certain target income in mind, then having an extra labor task would allow them to achieve that target with lower investment risk. However, this explanation is inconsistent with the findings in the full treatment where subjects also have a second labor opportunity. If the labor treatment results are being driven by income targeting, then we would expect a fairly similar treatment effect in the full treatment where subjects also have a second labor opportunity in addition to the option to subsequently evade taxes. Instead, the risk exposure in the full treatment is not statistically different from that of the control group.

\footnotetext{
similar results in an investment market.

${ }^{20}$ We are not aware of any laboratory studies of the effect of labor supply flexibility or labor income background risk on current risk exposure. See Heaton and Lucas (2000) for a survey of other observational studies with similar findings.

${ }^{21}$ Although we find this question interesting, addressing it requires additional design features that take us away from the central research question of this paper. We therefore view this question as somewhat outside the scope of the specific objective of this study, and believe it is best pursued in future work.
} 


\subsection{Internal Validity}

The results described above are based on data generated in a one-shot experiment using a between subject design and four randomly determined groups that are identical except for treatment status. Descriptive statistics of observable characteristics show that the groups are balanced along observables. This suggests that randomization into groups worked, which is crucial for identification in between-subject designed experiments (Charness et al. 2012). Additionally, the experimental instructions for the different treatment groups were identical in every aspect except for the opportunity to respond to the lottery. Since investment decisions in all groups are made before subjects proceed to the adjustment-stage, any differences in the outcome variable of interest, risk exposure, between groups are only driven by the knowledge about and anticipation of future (ex post) adjustment possibilities. The number of participants in the experiment is relatively large and we are able to rely on 45 independent observations per group because there is no interaction among participants. We find no evidence that the experimental design choices and parametrization induced extreme behaviors that conflict with standard theoretical modeling approaches. For example, the lottery outcomes are not clustered on extremes (0 or 1), which suggests that the resulting distribution of investment shares supports the theoretical modeling of an interior solution. Furthermore, labor supply is strictly positive but not statistically different across treatments. Additionally, the labor task yielded sufficient variation to support the idea of labor-income uncertainty.

\subsection{External Validity}

As with all economic laboratory experiments, there remains doubt about the external validity of our results. ${ }^{22}$ One major concern is that the setting in the lab is abstract and artificial. However, subjects in our experiment must complete a "real-effort" task for which they earn money dependent on their performance. While not perfectly equivalent to a naturally occurring environment, the effort task represents real economic choices and is similar to many "real-world" labor tasks in the sense that it is annoying and somewhat "painful". We argue that the sense of ownership induced by the labor task implies that subjects are more likely to make realistic choices in the investment stage of the experiment, which is important for the external validity of our results. In order to make the tax evasion decision as realistic as possible we used actual tax terminology and announced to the participants that all tax revenue will be donated to the administration of the City of Cologne. This latter feature mimics the spirit of taxes having no direct beneficial impact. We avoided charitable institutions to induce as much neutral attitude

\footnotetext{
${ }^{22}$ See Levitt and List (2007) for a critical discussion of the generalizability of lab experiments. Falk and Heckman (2009) offer a defense of most concerns, some of which are also discussed here.
} 
as possible. ${ }^{23}$

It is also often argued that the stakes in lab experiments are too small to interpret the outcomes as realistic. This is unlikely to be true in our case because subjects earned an average pay-off of EUR 13.13 in approximately 40 minutes, which corresponds to an hourly wage of approx. 19.70 EUR/25.64 USD or almost eight full lunch meals in the student cafeteria at Cologne University. ${ }^{24}$ Another concern is the reliance on university students as participants. Many experiments with non-student populations find results comparable to experiments with students (Charness and Kuhn 2011; Falk et al. 2012). Furthermore, Alm et al. (2011) compare students to non-students in tax compliance experiments and find that reporting responses of students to policy innovations are largely the same as non-students in identical experiments and "real" people in non-experiment environments.

\section{Conclusion}

While the literature acknowledges that labor supply flexibility and tax evasion opportunities are likely to affect investment outcomes, there is little empirical evidence on this relationship. Using a laboratory experiment, we examine if individuals who have the opportunity to (ex post) respond to lottery outcomes through evasion and/or labor supply show different (ex ante) risk willing behavior than individuals without any response opportunities. We find that the opportunity to supply extra labor has a different effect on the willingness to take risks than the opportunity to evade taxes. While extra labor opportunity largely and significantly reduces exposure to investment risks, tax evasion has no effect. The joint effect of both forms of adjustment opportunity is negative but not statistically different from zero.

Our study contributes to the tax evasion and finance literatures by identifying the impact of tax evasion opportunities on risk exposure. While heterogeneous access to tax evasion has been shown to affect labor supply elasticities with respect to taxes, income distribution and social welfare, we know of no other study to examine the effect of tax evasion on current risk exposure. Our results also contribute to the labor economic literature by providing insights into the possible effect of the current incremental shift toward greater flexibility in the labor market - e.g., flexi-week work schedules and workfrom-home initiatives - on risk exposure. We find that risk exposure is likely to decrease

\footnotetext{
${ }^{23}$ Tax morale research (Torgler 2007) finds that taxpayers are more likely to comply with the tax laws if they believe that the tax revenue is spent transparently. Eckel and Grossman (1996) show that dictators share more in dictator games if the recipient is the American Red Cross. Overall, we donated EUR 465.20 to the City of Cologne.

${ }^{24}$ The show-up fee is equivalent to one meal. The cafeteria at University of Cologne is the most popular spot for students to buy their daily lunch.
} 
if the added flexibility is accompanied by greater income uncertainty. Additionally, we explicitly account for any possible interaction effects between labor supply and evasion opportunities in our empirical design. Understanding these interaction effect is especially important given that labor flexibility and income uncertainty is often bundled with tax evasion opportunities (e.g., among the self-employed).

The results further contribute to the long standing financial asset puzzle; what explains the lower than expected stock market exposure of individuals. Our results suggest that heterogenous access to additional labor income, tax evasion opportunities and their interaction play a non-trivial role in determining risk exposure. This finding is both important and timely given a number of recent developments. For example, the increased scrutiny of offshore accounts imply reduced tax evasion opportunities for many high income individuals. Although this change may to lead to higher revenues, we show that it is unlikely to affect risk exposure.

\section{References}

Allingham, M. G. and A. Sandmo (1972). Income tax evasion: A theoretical analysis. Journal of Public Economics 1(3-4), 323-338.

Alm, J. (2012). Measuring, explaining, and controlling tax evasion: lessons from theory, experiments, and field studies. International Tax and Public Finance 19(1), 54-77.

Alm, J., K. M. Bloomquist, and M. McKee (2011). Comparing student and non-student reporting behavior in tax compliance experiments. In A. Plumley (Ed.), IRS Research Bulletin (Publication 1500), pp. 93-99. Washington D.C.: International Revenue Service.

Alm, J., B. R. Jackson, and M. McKee (2009). Getting the word out: Enforcement information dissemination and compliance behavior. Journal of Public Economics 93(3-4), 392-402.

Alm, J. and E. Sennoga (2011). Mobility, competition, and the distributional effects of tax evasion. Tulane Economics Working Paper Series No 1108.

Alm, J. and B. Torgler (2006). Culture differences and tax morale in the United States and in Europe. Journal of Economic Psychology 27(2), 224-246.

Arrow, K. J. (1965). Aspects of the Theory of Risk Bearing. Helsinki: Yrjo Johansson Saatio.

Benitez-Silva, H. (2002). Labor supply flexibility and portfolio choice: An empirical analysis. In D. K. L. W. Zame, A. Case, R. Fernandez, J. Rust, and K. Wolpin (Eds.), Proceedings of the 2002 North American Summer Meetings of the Econo- 
metric Society: Labor Economics and Applied Econometrics. North Holland. http: //www.dklevine.com/proceedings/labor-economics.htm.

Bodie, Z., R. C. Merton, and W. F. Samuelson (1992). Labor supply flexibility and portfolio choice in a life cycle model. Journal of Economic Dynamics and Control 16(3-4), 427-449.

Bricker, J., A. Kennickell, K. Moore, and J. Sabelhaus (2012). Changes in u.s. family finances from 2007 to 2010: Evidence from the survey of consumer finances. Federal Reserve Bulletin 98(2), 1-80.

Cettolin, E. and A. Riedl (2011). Fairness and uncertainty. mimeo, Maastricht University.

Charness, G. and U. Gneezy (2012). Strong evidence for gender differences in risk taking. Journal of Economic Behavior \& Organization 83(1), 50-58.

Charness, G., U. Gneezy, and M. A. Kuhn (2012). Experimental methods: Betweensubject and within-subject design. Journal of Economic Behavior \&5 Organization $81(1), 1-8$.

Charness, G. and P. Kuhn (2011). Lab labor: What can labor economists learn from the lab? In O. Ashenfelter and D. Card (Eds.), Handbook of Labor Economics Vol 4A, pp. 229-330. Amsterdam: North Holland.

Chetty, R. (2009). Is the taxable income elasticity sufficient to calculate deadweight loss? the implications of evasion and avoidance. American Economic Journal: Economic Policy 1(2), 31-52.

Cramer, J. S., J. Hartog, N. Jonker, and C. M. Van Praag (2002). Low risk aversion encourages the choice for entrepreneurship: an empirical test of a truism. Journal of Economic Behavior 8 Organization 48(1), 29-36.

Djawadi, B. M. and R. Fahr (2012). The impact of tax knowledge and budget spending influence on tax compliance. mimeo, University of Paderborn.

Doerrenberg, P. and D. Duncan (2012). Experimental evidence on the relationship between tax evasion opportunities and labor supply. IZA Discussion Paper No. 6941.

Eckel, C. C. and P. J. Grossman (1996). Altruism in anonymous dictator games. Games and Economic Behavior 16(2), 181-191.

Falk, A. and J. J. Heckman (2009). Lab experiments are a major source of knowledge in the social sciences. Science 326 (5952), 535-538.

Falk, A., S. Meier, and C. Zehnder (2012). Do lab experiments misrepresent social preferences? The case of self-selected student samples. Journal of the European Economic Association. Forthcoming. 
Fischbacher, U. (2007). z-tree: Zurich toolbox for ready-made economic experiments. Experimental Economics 10(2), 171-178.

Franke, G., H. Schlesinger, and R. C. Stapleton (2011). Risk taking with additive and multiplicative background risks. Journal of Economic Theory 146(4), 1547-1568.

Gakidis, H. (1997). Stocks for the old? Earnings uncertainty and life-cycle portfolio choice. manuscript.

Gill, D. and V. Prowse (2012). A structural analysis of disappointment aversion in a real effort competition. American Economic Review 102(1), 469-503.

Gill, D. and V. Prowse (2013a). A novel computerized real effort task based on sliders. Oxford Department of Economics Discussion Paper 435.

Gill, D. and V. L. Prowse (2013b). Gender differences and dynamics in competition: The role of luck. Quantitative Economics. forthcoming.

Gneezy, U., A. Kapteyn, and J. Potters (2003, 04). Evaluation periods and asset prices in a market experiment. Journal of Finance 58(2), 821-838.

Gneezy, U. and J. Potters (1997). An experiment on risk taking and evaluation periods. The Quarterly Journal of Economics 112(2), pp. 631-645.

Gollier, C. (2001). The economics of risk and time, Volume 68. MIT Press.

Gollier, C. and R. Zeckhauser (2002). Horizon length and portfolio risk. Journal of Risk and Uncertainty 24(3), 195-212.

Gorodnichenko, Y., J. Martinez-Vazquez, and K. Sabirianova Peter (2009). Myth and reality of flat tax reform: Micro estimates of tax evasion response and welfare effects in russia. Journal of Political Economy 117(3), 504-554.

Greiner, B. (2004). An online recruitment system for economic experiments. In K. Kremer and V. Macho (Eds.), Forschung und wissenschaftliches Rechnen 2003. GWDG Bericht 63, pp. 79-93. Goettingen: Ges. fuer Wiss. Datenverarbeitung.

Halla, M. (2012). Tax morale and compliance behavior: First evidence on a causal link. The B.E. Journal of Economic Analysis 8 Policy 12(1).

Hammermann, A., A. Mohnen, and P. Nieken (2012). Whom to choose as a team mate? A lab experiment about in-group favouritism. IZA Discussion Papers 6286.

Hartog, J., A. Ferrer-i Carbonell, and N. Jonker (2002). Linking measured risk aversion to individual characteristics. Kyklos 55(1), 3-26.

Heaton, J. and D. Lucas (2000). Portfolio choice in the presence of background risk. The Economic Journal 110(460), 1-26.

Inglehart, R. (n.d.). Values change the world. http://worldvaluessurvey.org/ (accessed April 2010). 
Kleven, H. J., M. B. Knudsen, C. T. Kreiner, S. Pedersen, and E. Saez (2011). Unwilling or unable to cheat? Evidence from a tax audit experiment in Denmark. Econometrica 79(3), 651-692.

Klos, A. (2004). The investment horizon and dynamic asset allocation-some experimental evidence. Economics Letters 85(2), 167-170.

Klos, A., E. U. Weber, and M. Weber (2005). Investment decisions and time horizon: Risk perception and risk behavior in repeated gambles. Management Science 51(12), 1777-1790.

Klos, A. and M. Weber (2006). Portfolio choice in the presence of non-tradable income: An experimental analysis. German Economic Review 7(4), 427-448.

Levitt, S. D. and J. A. List (2007). What do laboratory experiments measuring social preferences reveal about the real world? The Journal of Economic Perspectives $21(2), 153-174$.

Mossin, J. (1968). Optimal multiperiod portfolio policies. The Journal of Business 41(2), 215-229.

Pratt, J. W. (1964). Risk aversion in the small and in the large. Econometrica 32, 122-136.

Riener, G. and S. Wiederhold (2011). On social identity, subjective expectations, and the costs of control. Jena Economic Research Papers 2011-035.

Slemrod, J. (2003). Trust in public finance. In S. Cnossen and H.-W. Sinn (Eds.), Public Finance and Public Policy in the New Century, pp. 49-88. Cambridge, USA: The MIT Press.

Thaler, R. H., A. Tversky, D. Kahneman, and A. Schwartz (1997). The effect of myopia and loss aversion on risk taking: An experimental test. The Quarterly Journal of Economics 112(2), 647-661.

Torgler, B. (2007). Tax Compliance and Tax Morale: A Theoretical and Empirical Analysis. Cheltenham, UK: Edward Elgar.

Wrede, M. (1995). Tax evasion and risk taking: Is tax evasion desirable? Public Finance / Finances Publique 50(2), 303-316. 


\section{Appendices}

\section{A Screens in the Lab Experiment}

Figure 3: Screen showing the slider task

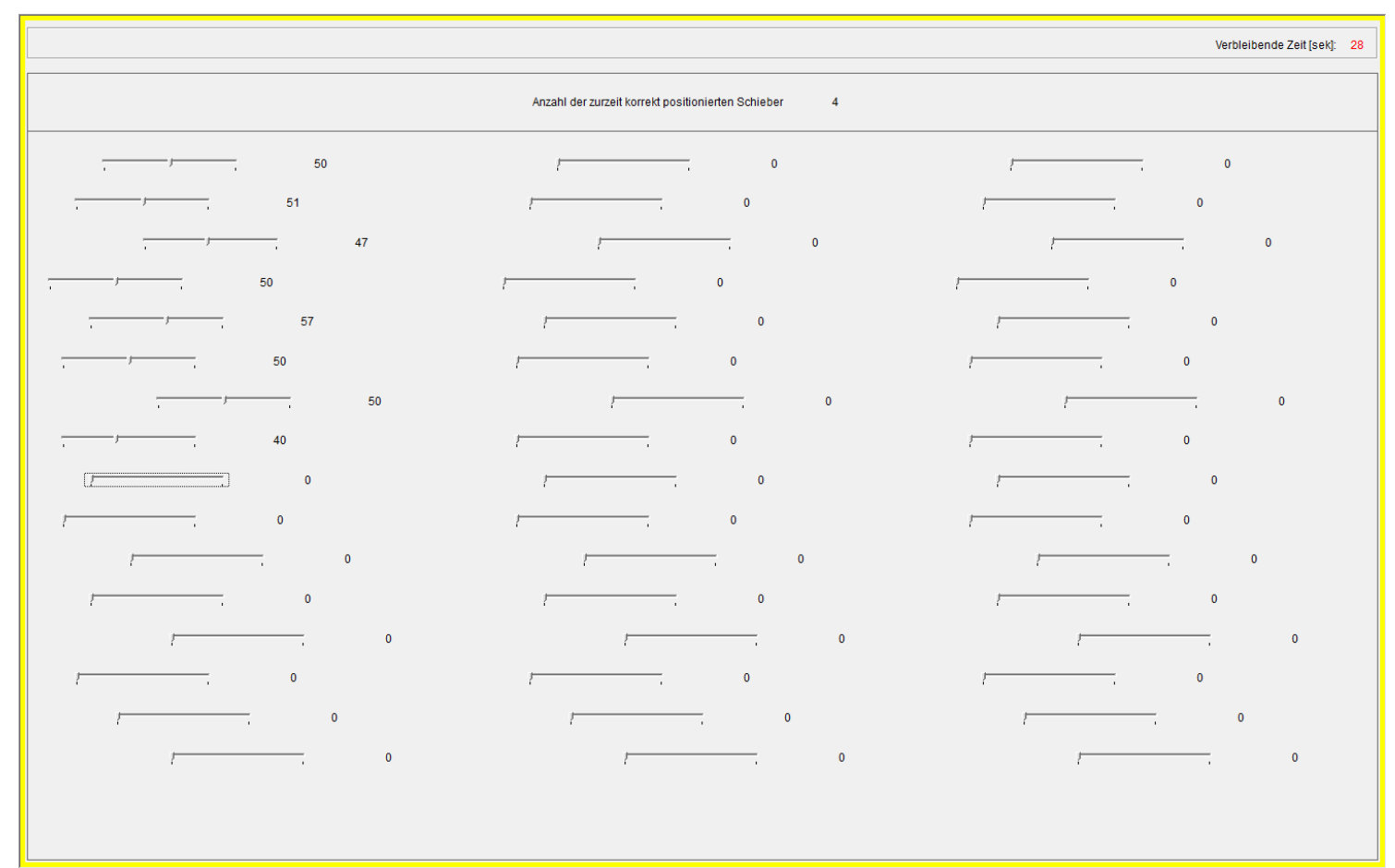

Note: Screen showing the slider task which was designed by Gill and Prowse (2012). In the displayed screen, the subject positioned four sliders correctly and four falsely. She currently works on positioning the ninth slider. 28 seconds are left in this round. 
Figure 4: Screen showing the investment decision

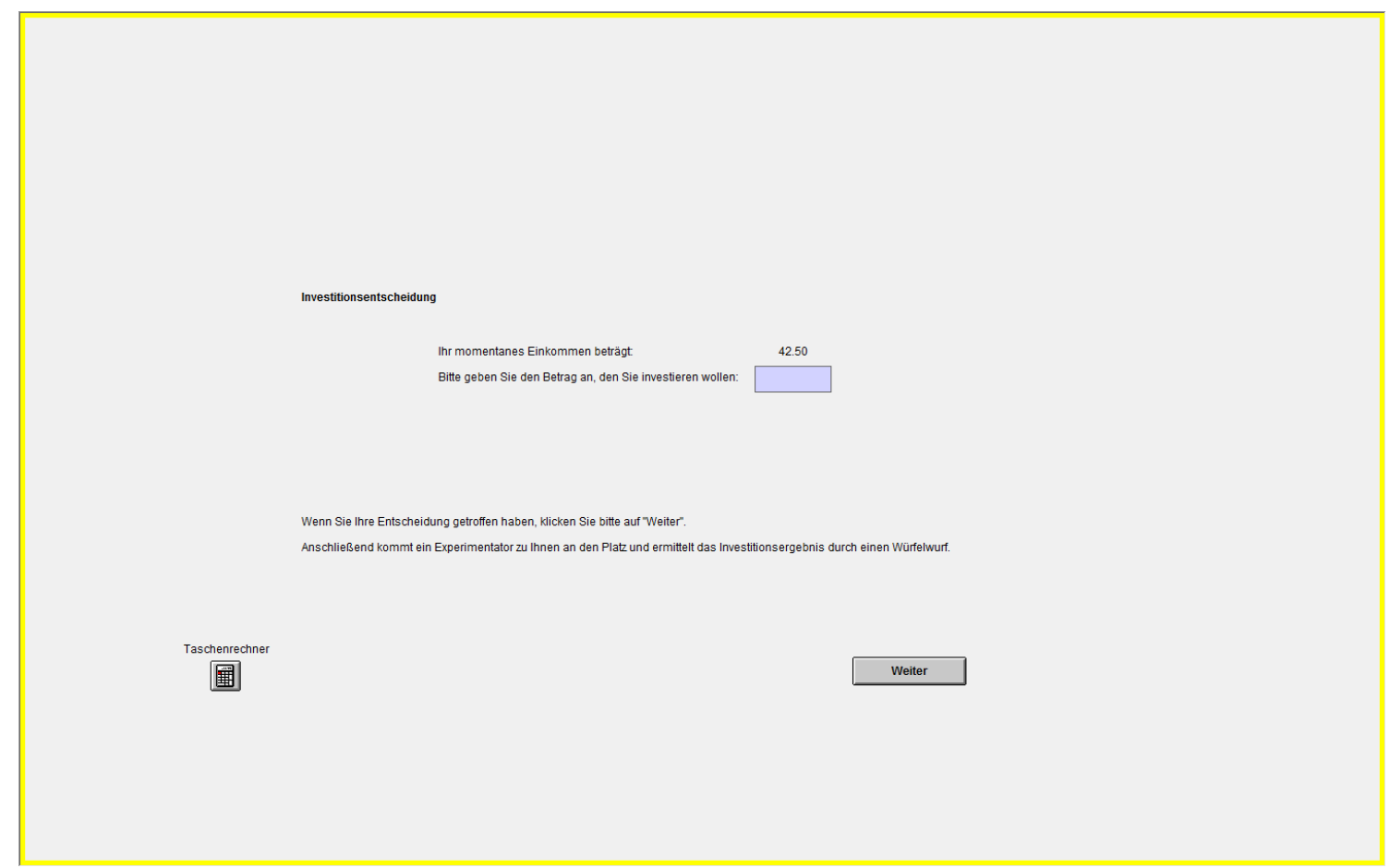

Figure 5: Screen showing the investment decision

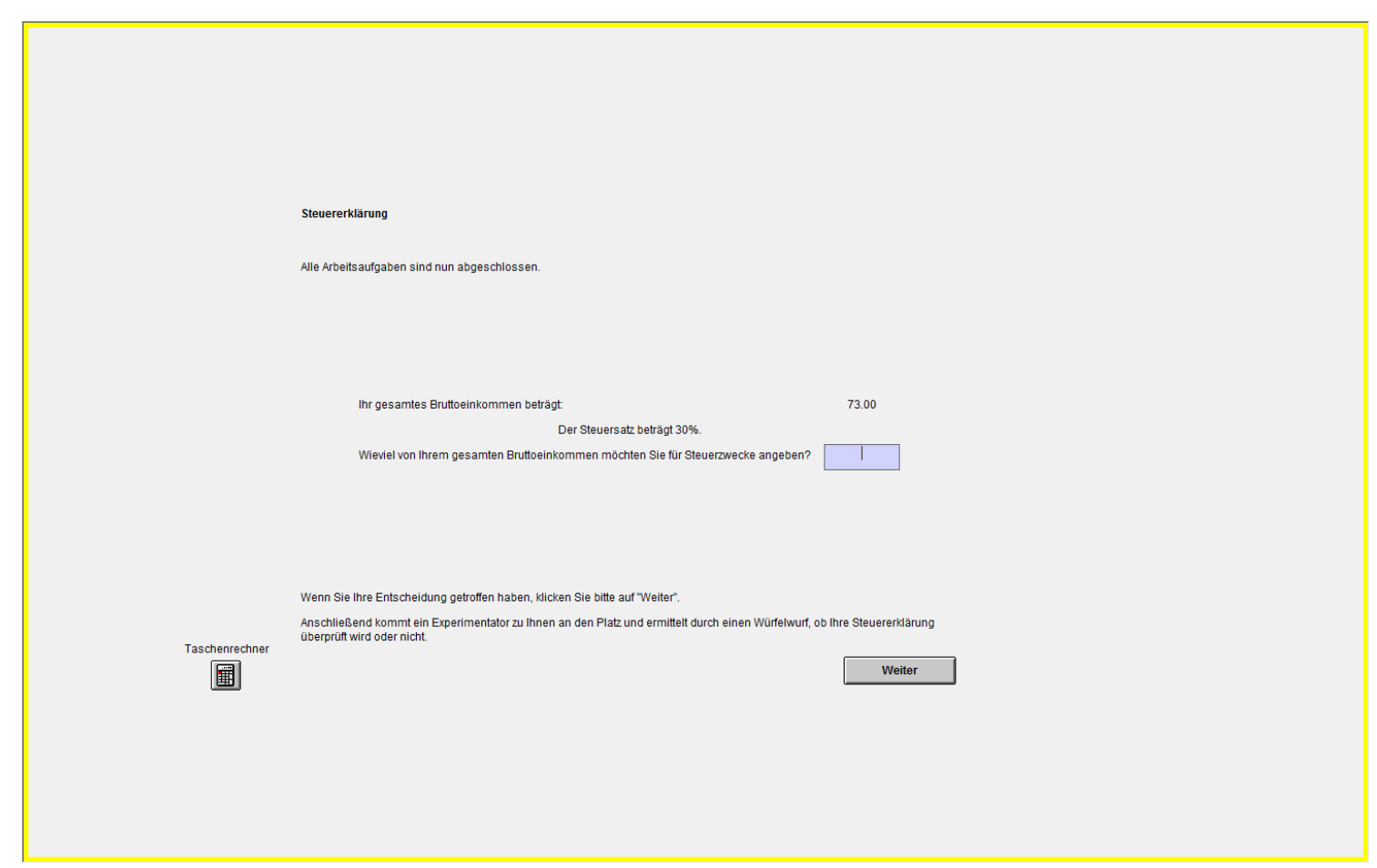

\section{B Distribution of Labor by Treatment group}




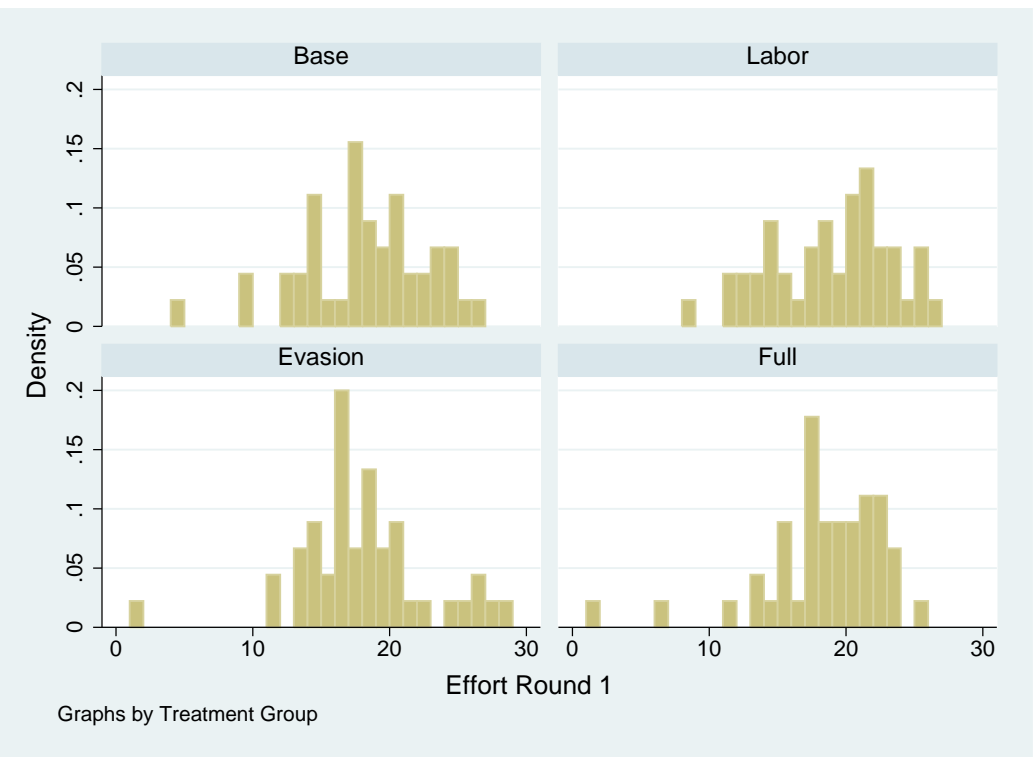

Figure 6: Distribution of Round 1 Effort

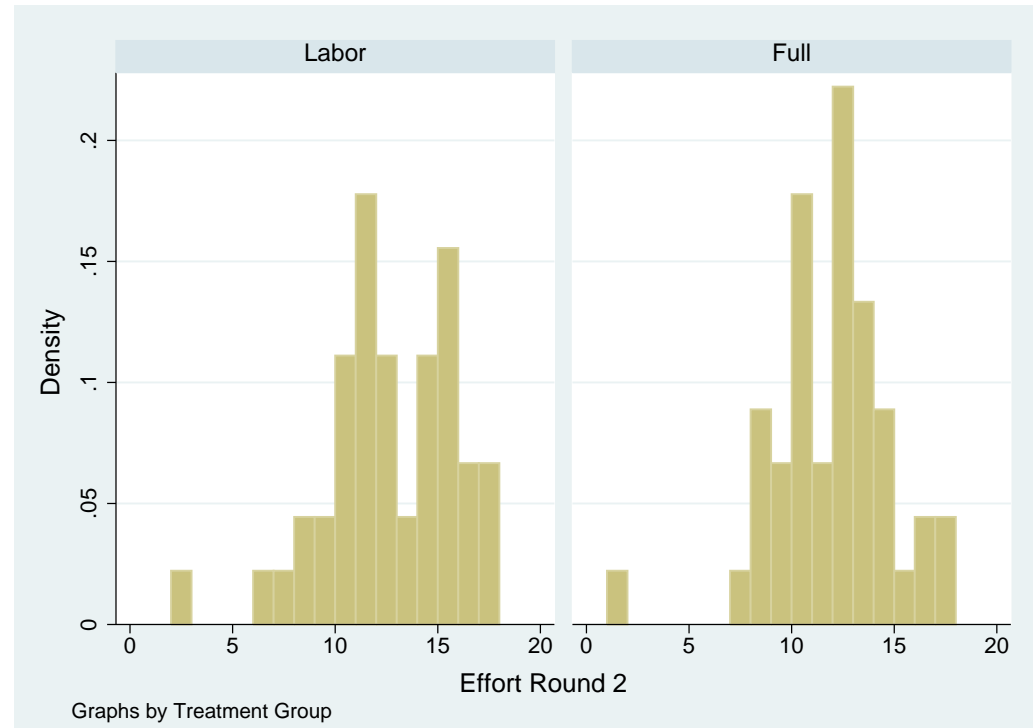

Figure 7: Distribution of Round 2 Effort 


\section{Detailed Regression Results}

Table 4: Treatment Effects on Investment Behavior: OLS and Tobit Regressins

\begin{tabular}{|c|c|c|c|c|}
\hline Model & (I) & (II) & (III) & (IV) \\
\hline Estimation & OLS & OLS & Tobit & Tobit \\
\hline \multirow[t]{2}{*}{ Labor } & $-0.111^{* *}$ & $-0.102^{* *}$ & $-0.128^{* *}$ & $-0.114^{* *}$ \\
\hline & $(0.054)$ & $(0.051)$ & $(0.063)$ & $(0.057)$ \\
\hline \multirow[t]{2}{*}{ Evasion } & -0.007 & -0.018 & -0.016 & -0.027 \\
\hline & $(0.060)$ & $(0.061)$ & $(0.071)$ & $(0.070)$ \\
\hline \multirow[t]{2}{*}{ Full } & -0.035 & -0.041 & -0.058 & -0.062 \\
\hline & $(0.061)$ & $(0.058)$ & $(0.073)$ & $(0.069)$ \\
\hline \multirow[t]{2}{*}{ Age } & & $0.009 * * *$ & & $0.012^{* * *}$ \\
\hline & & $(0.003)$ & & $(0.004)$ \\
\hline \multirow[t]{2}{*}{ Male } & & $0.098 * *$ & & $0.108^{* *}$ \\
\hline & & $(0.040)$ & & $(0.047)$ \\
\hline \multirow[t]{2}{*}{ German } & & -0.004 & & -0.012 \\
\hline & & $(0.042)$ & & $(0.046)$ \\
\hline \multirow[t]{2}{*}{ Tax Morale } & & 0.004 & & 0.004 \\
\hline & & $(0.007)$ & & $(0.008)$ \\
\hline \multirow[t]{2}{*}{ Risk (indiff.) } & & 0.132 & & 0.154 \\
\hline & & $(0.087)$ & & $(0.097)$ \\
\hline \multirow[t]{2}{*}{ Risk (seeking) } & & $0.202^{* * *}$ & & $0.222^{* * *}$ \\
\hline & & $(0.061)$ & & $(0.065)$ \\
\hline \multirow[t]{2}{*}{ Constant } & $0.381^{* * *}$ & $0.261^{* *}$ & $0.387^{* * *}$ & 0.213 \\
\hline & $(0.044)$ & $(0.118)$ & $(0.053)$ & $(0.144)$ \\
\hline $\mathrm{N}$ & 180 & 180 & 180 & 180 \\
\hline $\mathrm{R} 2$ & 0.028 & 0.176 & 0.030 & 0.219 \\
\hline
\end{tabular}

OLS and two-censored (at 0 and 1) Tobit regressions based on equation 6 . Dependent variable is the share of period 1 labor income invested in the lottery. Treatment effects are relative to the omitted control group without adjustment opportunities. Subjects in the Labor and Evasion treatments had the opportunity to supply extra effort and evade taxes, respectively. Full treatment indicates that both labor and evasion adjustments were available. Subjects in the control group had no adjustment opportunities. Robust standard errors in parentheses. Estimations (II) and (IV) include control variables. ${ }^{*}<0.10,{ }^{* *}<0.05,{ }^{* * *}<0.01$ 


\section{Original Instructions}

The following pages display the instructions in German (original) and English (translated) for the "Full Treatment" Group. The instructions for the other groups are the same but exclude the parts which were not relevant for the respective group (these are available upon request). 


\section{Instruktionen}

Herzlich willkommen und vielen Dank für Ihre Teilnahme an diesem Experiment. Bitte kommunizieren Sie ab sofort und bis zum Ende des Experimentes nicht mehr mit den anderen Teilnehmern. Sollten Sie sich nicht an diese Regel halten, müssen wir Sie von dem Experiment ausschließen.

Wir bitten Sie, die Instruktionen sehr aufmerksam zu lesen. Wenn Sie nach dem Lesen oder während des Experiments noch Fragen haben, heben Sie bitte Ihre Hand. Einer der Experimentleiter wird dann zu Ihnen kommen und Ihre Frage persönlich beantworten. Ihre Auszahlung und Ihre Entscheidungen werden vertraulich behandelt. Keiner der anderen Teilnehmer erfährt während oder nach dem Experiment, welche Entscheidungen Sie getroffen haben oder wie hoch Ihre Auszahlung war.

Sie können in diesem Experiment Geld verdienen. Wie viel Sie verdienen, hängt von Ihren Entscheidungen $\mathrm{ab}$ und wird nicht von den Entscheidungen anderer Teilnehmer beeinflusst. Ihre Auszahlungen werden im Laufe des Experimentes in virtuellen Geldeinheiten, den Experimental Currency Units (ECU), angegeben. 5 ECU entsprechen 1 EUR. Ihre Auszahlung wird nach dem Ende des Experimentes in Euro umgerechnet und in bar an Sie ausgezahlt. Zusätzlich erhalten Sie für Ihr Erscheinen eine Teilnahmepauschale in Höhe von 2,50 EUR.

\section{Das Experiment}

\section{Überblick}

Das Experiment besteht aus einer Übungsrunde und einer Auszahlungsrunde. Sie können in der Übungsrunde kein Geld verdienen.

Die Auszahlungsrunde hat vier Phasen:

Phase 1 (Arbeitsaufgabe 1): Sie erledigen eine Arbeitsaufgabe und erhalten dafür, abhängig von Ihrer Leistung, Geldeinheiten.

Phase 2 (Investitionsentscheidung): Sie können Ihr in Phase 1 verdientes Geld entweder in eine Anlage mit zufälliger Auszahlung investieren oder aufbewahren. Sie entscheiden in dieser zweiten Phase, wie viel Sie investieren möchten.

Phase 3 (Arbeitsaufgabe 2): Sie wiederholen die Arbeitsaufgabe aus Phase 1 und erhalten dafür, abhängig von Ihrer Leistung, zusätzliche Geldeinheiten.

Phase 4 (Steuererklärung): Auf Ihr gesamtes Einkommen aus den ersten drei Phasen fällt eine Steuer an. In dieser vierten Phase des Experiments geben Sie eine Steuererklärung ab.

Die Übungsrunde zu Beginn des Experiments dient dazu, Sie mit der Arbeitsaufgabe vertraut zu machen und umfasst daher nur die Arbeitsaufgabe. Alle Phasen des Experiments werden im Folgenden ausführlicher erklärt. 


\section{Phase 1: Arbeitsaufgabe 1}

Sie erledigen an Ihrem Bildschirm eine Arbeitsaufgabe mit Hilfe der Computermaus. Die Arbeitsaufgabe dauert 150 Sekunden. Während der Arbeitsaufgabe erscheint ein Bildschirm, auf dem 48 sogenannte „Schieber“ zu sehen sind. Jeder Schieber ist zunächst auf „,0“ (Null) positioniert und kann von Ihnen verschoben werden. Sie können den Schieber mit der Computermaus auf jede ganze Zahl zwischen „0“ und „100“ verschieben. Sie können jeden Schieber so oft verschieben, wie Sie möchten. Sie erhalten 2,50 ECU für jeden Schieber, den Sie innerhalb der 150 Sekunden exakt auf der Nummer ,50“ positionieren. Oben rechts am Bildschirm können Sie während der 150 Sekunden immer ablesen, wie viele Schieber Sie aktuell auf ,50“ positioniert haben. Zusätzlich zu Ihrer Bezahlung für die korrekt positionierten Schieber erhalten Sie eine fixe Ausstattung von 2,50 ECU.

\section{Phase 2: Investitionsentscheidung}

Sie haben die Wahl, einen Teil Ihres Geldes oder Ihr gesamtes Geld, welches Sie in Phase 1 verdient haben, aufzubewahren oder zu investieren. Das aufbewahrte Geld steht Ihnen unverändert im weiteren Verlauf des Experiments zur Verfügung. Durch Investieren können Sie zusätzliches Geld gewinnen oder einen Teil Ihres Geldes verlieren. Das Geld, das Sie investieren, wird entweder verdoppelt oder halbiert. Beide Ergebnisse sind gleich wahrscheinlich.

Nachdem Sie entschieden haben, wie viel Sie investieren möchten, wird ein Experimentator an Ihren Platz kommen und einen 10-seitigen Würfel mitbringen. Der Experimentator wird an Ihrem Platz auswürfeln, ob Ihr investiertes Geld verdoppelt oder halbiert wird. Zeigt der 10-seitige Würfel eine Zahl zwischen 1 und 5 (also 1, 2, 3, 4 oder 5), dann wird Ihre Investition halbiert. Wird eine Zahl zwischen 6 und 10 geworfen (also 6, 7, 8, 9 oder 10), dann wird Ihre Investition verdoppelt.

Ihr Einkommen, das Ihnen im weiteren Verlauf des Experiments zur Verfügung steht, besteht also aus dem aufbewahrten Betrag zuzüglich des entweder verdoppelten oder halbierten Investitionsbetrags. Somit gilt abhängig vom Würfelergebnis für Ihr Einkommen:

- Würfel zeigt eine Zahl zwischen 1 und 5:

Einkommen $=$ Aufbewahrt $+(0,5 \mathrm{x}$ Investition $)$

- Würfel zeigt eine Zahl zwischen 6 und 10:

Einkommen $=$ Aufbewahrt $+(2 \mathrm{x}$ Investition $)$

\section{Phase 3: Arbeitsaufgabe 2}

Das Investitionsergebnis wird bestimmt und auf ihrem Bildschirm angezeigt. Sie erledigen danach die gleiche Arbeitsaufgabe wie in Phase 1. Diesmal erhalten Sie jedoch keinen zusätzlichen Fixbetrag. Außerdem dauert diese zweite Arbeitsaufgabe 90 Sekunden. Das Geld, das Sie in dieser Arbeitsaufgabe verdienen, wird zu Ihrem bisherigen Geld hinzuaddiert. 


\section{Phase 4: Steuererklärung}

Ihnen wird zunächst Ihr gesamtes aktuelles Einkommen angezeigt. Dieses Einkommen bildet Ihr Bruttoeinkommen, auf das eine Steuer von 30\% fällig wird.

Sie sind nun aufgefordert, eine Steuererklärungsentscheidung zu treffen. Dazu benennen Sie einen Betrag, der mit dem Steuersatz von 30\% besteuert werden soll. Dieser genannte Betrag kann zwischen Null und der Höhe Ihres gesamten Bruttoeinkommens liegen.

Nachdem Sie Ihre Steuererklärungsentscheidung getroffen haben, warten Sie bitte bis einer der Experimentatoren an Ihren Platz kommt. Der Experimentator wird einen 10-seitigen Würfel mitbringen und an Ihrem Platz werfen.

Basierend auf dem Ergebnis des Würfelwurfs ergibt sich eines der zwei folgenden Szenarien für Ihr Nettoeinkommen, das Ihnen am Ende des Experiments zusammen mit der Teilnahmepauschale ausgezahlt wird:

\section{Szenario a) Der Würfel zeigt eine Zahl zwischen 2 und 10:}

Es wird nicht überprüft, ob Sie in Ihrer Steuererklärungsentscheidung Ihr Bruttoeinkommen vollständig angezeigt haben. Ihre Auszahlung (das Nettoeinkommen) setzt sich in diesem Fall aus dem Bruttoeinkommen abzüglich der Steuerzahlung zusammen. Dabei ist die Steuerzahlung der Betrag, den Sie in der Steuererklärung angegeben haben, multipliziert mit dem Steuersatz von 30\%. Also:

$\rightarrow \quad$ Nettoeinkommen $=$ Bruttoeinkommen $-($ angegebener Betrag $\mathrm{x} 0,30)$

Szenario b) Der Würfel zeigt die Zahl 1:

Es wird überprüft, ob Sie in der Steuererklärung Ihr vollständiges Bruttoeinkommen angegeben haben. Abhängig von Ihrer vorher getroffenen Steuererklärungsentscheidung, gibt es in diesem Fall für Ihr Nettoeinkommen zwei Möglichkeiten:

- Ist der von Ihnen in der Steuererklärung angegebene Betrag gleich Ihrem gesamten Bruttoeinkommen, dann setzt sich Ihr Nettoeinkommen aus dem Bruttoeinkommen minus der Steuerverbindlichkeit zusammen. Also:

$\rightarrow \underline{\text { Nettoeinkommen }}=$ Bruttoeinkommen $-($ Bruttoeinkommen $\times 0,30)$

- Ist der von Ihnen in der Steuererklärung angegebene Betrag niedriger als Ihr gesamtes Bruttoeinkommen, dann müssen Sie die volle Steuerzahlung basierend auf Ihrem gesamten Bruttoeinkommen zahlen. Außerdem fällt eine Extrazahlung an. Diese Extrazahlung errechnet sich durch den von Ihnen nicht angegebenen Betrag multipliziert mit dem Steuersatz von 30\%. Also:

$\rightarrow \underline{\text { Nettoeinkommen }}=$ Bruttoeinkommen $-($ Bruttoeinkommen $x$ 0,30) - [ (Bruttoeinkommen - angegebener Betrag) x 0,30] 
Es besteht also eine Wahrscheinlichkeit von 10\%, dass Ihre Steuererklärungsentscheidung überprüft wird. Dem Experimentator ist es selbstverständlich nicht möglich, einzusehen, ob Sie Ihr Bruttoeinkommen in voller Höhe angegeben haben oder nicht.

Die von allen Teilnehmern insgesamt geleisteten Steuerzahlungen werden an die Verwaltung der Stadt Köln als Spende überwiesen. Ein Nachweis über die Gesamtspende wird Ihnen im Laufe der nächsten Wochen per Email zugeschickt.

\section{Schlussbemerkungen}

Am Ende des Experiments bitten wir Sie, einen kurzen Fragebogen auszufüllen während wir die Auszahlungen vorbereiten. Alle dort angegebenen Informationen, sowie alle während dieses Experiments erhobenen Daten, werden selbstverständlich anonymisiert und ausschließlich für wissenschaftliche Zwecke verwendet. 


\section{Instructions}

Welcome and thank you for participating in our experiment. From now on until the end of the experiment, please refrain from communicating with other participants. If you do not abide by this rule, we will have to exclude you from the experiment.

We kindly ask you to read the instructions thoroughly. If you have any questions after reading the instructions or during the experiment, please raise your hand. One of the instructors will then come to you and answer your question in person. Your payment and your decisions throughout the experiment will be treated confidentially. None of the other participants is informed, neither during nor after the experiment, about your decisions in the experiment or your payment.

You can earn money in this experiment. How much you earn depends on your decisions and is not affected by the decisions of other participants. During the experiment, your payments will be calculated in a virtual currency: Experimental Currency Units (ECU). 5 ECU corresponds to 1 EUR. After the experiment, your pay-off will be converted to Euro and given to you in cash. Additionally, you will receive a show-up fee of 2.50 EUR.

\section{The Experiment}

\section{Overview}

The experiment consists of one practice round and one payoff round. You cannot earn money in the practice round.

The payoff round has four stages.

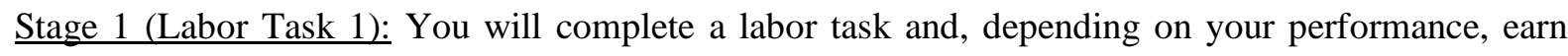
money from this labor task.

Stage 2 (Investment Decision): You can either invest the money that you earned in stage 1 in an asset with a random payoff or store it. You decide in this second stage, how much you want to invest.

Stage 3 (Labor Task 2): You will repeat the labor task from stage 1 and, depending on your performance, earn additional money from this labor task.

Stage 4 (Tax Declaration): You will have to pay taxes on your total income from the first three stages. In this fourth stage, you have to file a tax declaration.

The practice round at the beginning of the experiment is meant to acquaint yourself with the labor task and, hence, only involves the labor task. All stages of the experiment will be explained in more detail below.

\section{Stage 1: Labor Task 1}


You undertake a labor task on the computer screen using the computer mouse. The task will last 150 seconds. During the task a screen with 48 so-called "sliders" appears on the screen. Each slider is initially positioned at "0" (Zero) and can be moved by you. You can move the slider to every integer between " 0 " and " 100 " via the computer mouse. You can readjust the position of each slider as many times as you wish. For each slider that you position exactly at the number "50" during the 150 seconds, you earn $\mathbf{2 . 5 0}$ ECU. During the 150 seconds of the labor task, on the upper right of the screen you are shown how many sliders you have currently positioned at " 50 ". In addition to your result for the correctly positioned sliders, you receive an additional fixed endowment of 2.50 ECU.

\section{Stage 2: Investment Decision}

You will be given the choice to store or invest some or all of the money that you earned in stage 1 . The money that you store will be available unchanged in the future course of the experiment. By investing, you can gain additional money or lose some of your money. The money that you invest will be either doubled or halved. Both outcomes are equally likely.

After you have decided how much to invest, an experimenter will come to your booth and bring a 10-sided die. At your booth, the experimenter will roll the die to decide if your invested money is doubled or halved. If the 10-sided die shows a number between 1 and 5 (i.e., 1, 2, 3, 4 or 5), then your investment will be halved. If it shows a number between 6 and 10 (i.e., 6, 7, 8, 9 or 10), then your investment will be doubled.

Your income that will be available in the future course of the experiment hence consists of the stored amount plus the, either halved or doubled, investment amount. Hence, depending on the die roll, your income is:

- Die shows a number between 1 and 5:

Income $=$ Stored $+(0.5 \mathrm{x}$ Investment $)$

- Die shows a number between 6 and 10:

Income $=$ Stored $+(2 \mathrm{x}$ Investment $)$

\section{Stage 3: Labor Task 2}

The investment outcome will be determined and displayed on your computer screen. You will then undertake the same labor task as in stage 1 . However, you will not receive an additional fixed amount this time. In addition, this second labor task lasts 90 seconds. The money that you earn in this labor task will be added to the money that you have earned so far.

\section{Stage 4: Tax Declaration}

You will first be shown your full current income. This income is your gross income which is subject to tax of $30 \%$. 
You will now be asked to make a tax-declaration decision. To make this decision, you specify an amount which will be taxed at the tax rate of $30 \%$. This reported amount can be between zero and your full gross income.

After you have completed the tax-declaration decision, please wait until one of the experimenters comes up to your booth. The experimenter will bring a 10 -sided die and roll it at your booth.

Depending on the outcome of the die roll, you will face one of the following two scenarios regarding your net income which will be paid to you, along with the show-up fee, at the end of the experiment.

Scenario a) The die shows a number between 2 and 10:

Your tax-declaration decision will not be checked to determine whether you specified your full gross income. Your payment (the net income), in this case, consists of your gross income less the tax payment. The tax payment is the amount that you reported multiplied with the tax rate of $30 \%$. Hence:

$\rightarrow \quad$ Net Income $=$ Gross Income $-($ Reported Amount x 0.30)

Scenario b) The die shows the number 1:

Your tax-declaration decision will be checked to determine whether you reported your full gross income. Depending on your previous tax-declaration decision, there are two possibilities for your net income:

- If your reported income equals your full gross income, then your net income consists of your gross income less your tax liability. Hence:

$\rightarrow$ Net Income $=$ Gross Income $-($ Gross Income x 0.30)

- If your reported income is lower than your full gross income, then you will have to pay the full tax liability based on your full gross income. In addition, you have to pay an extra amount. This extra amount is equal to the income that you did not report multiplied by the tax rate of $30 \%$. Hence:

$\rightarrow \underline{\text { Net Income }}=$ Gross Income $-($ Gross Income $* 0.30)$

- [(Gross Income - Reported Income) x 0.30]

Hence, there is a $10 \%$ probability that your tax-declaration decision will be checked. The experimenter who comes up to your booth with the die, of course, cannot see whether or not you reported your full gross income. The total generated tax payments from all participants will be donated to the administration of the City of Cologne. A verification of the total donation will be sent to you via e-mail within the next weeks.

\section{Final Remarks}

At the end of the experiment, you will be asked to complete a short questionnaire while we prepare the payments. All information collected through this questionnaire, just like all data gathered during the experiment, are anonymous and exclusively used for scientific purposes. 